Amasya Ilahiyat Dergisi - Amasya Theology Journal

ISSN 2667-7326 | e-ISSN 2667-6710

Haziran / June 2021, 16: 59-88

\title{
Tefsir Literatürü Işı̆̆ı̀nda İsrâ Olayından Önce Nâzil Olan Sûrelerde Namaz
}

\section{Mehmet ALTUNTAŞ}

Doç. Dr., Yozgat Bozok Üniversitesi, İlahiyat Fakültesi,

Tefsir Anabilim Dalı

Associate Professor, Yozgat Bozok University, Faculty of Theology,

Department of Tafsir

Yozgat, Turkey

mehmet.altuntas@yobu.edu.tr

orcid.org/0000-0003-3702-2126

\section{Makale Bilgisi / Article Information}

Makale Türü / Article Types: Araştırma Makalesi / Research Article

Geliş Tarihi / Received: 13 Ocak / January 2021

Kabul Tarihi / Accepted: 18 Mart / March 2021

Yayın Tarihi / Published: 30 Haziran / June 2021

Yayın Sezonu / Pub. Date Season: Haziran / June

Sayı / Issue: 16 Sayfa / Pages: 59-88

Atıf / Cite as: Altuntaş, Mehmet. “Tefsir Literatürü Işığında İsrâ Olayından Önce Nâzil Olan Sûrelerde Namaz [In the Light of Tafsīr Literature, Prayer (Salāt) in the Sūrahs Sent Down before the Event of Isrā']". Amasya İlahiyat Dergisi-Amasya Theology Journal 16 (June 2021): 59-88.

https://doi.org/10.18498/amailad.860707.

İntihal / Plagiarism: Bu makale, en az iki hakem tarafından incelendi ve intihal içermediği teyit edildi. / This article has been reviewed by at least two referees and scanned via a plagiarism software.

Copyright @ P Published by Amasya Üniversitesi, İlahiyat Fakültesi / Amasya University, Faculty of Theology, Amasya, 05100 Turkey. All rights reserved. https://dergipark.org.tr/amailad. 
60 | M. ALTUNTAŞ / Tefsir Literatürü Işı̆̆ında İsrâ Olayından Önce Nâzil Olan Sûrelerde Namaz

\section{In the Light of Tafsīr Literature, Prayer (Salāt) in the Sūrahs Sent Down before the Event of Isrā'}

\section{Abstract}

There are many narrations in the Hadith books that prayer was performed in Mecca as two rak'ats, morning and evening, and then increased to five times. The general acceptance is that the five-time prayer is obliged after the Mi'rāj, taking into account the story about the event of Mi'rāj. Yet, there are disputes between the mufassirs about when the five-time prayer began. Although prayer worship is mentioned in sūrahs al-'Alaq, al-Muzzammil, al-Muddaththir, al-A'lā, al-Tīn, al-'Așr, al-Kawthar, al-Najm, al-Mā'ūn, al-A 'rāf, al-Jinn, al-Furqān, Fāṭir, Maryam, al-Shu'arā' and al-Naml, which was sent down before al-Isrā' according to nuzūl revelation orders, there is no direct word about the time of prayer in these sūrahs. Only some mufassirs have interpreted the word " așr" in sūrah 'Așr as the time of afternoon prayer.

The disputes about whether prayer begins as five times before or after Mi'rāj are formed in the context of tafsīr of verses Qāf 39-40 and Țā Hā 130, which are sent down before sūrah al-Isrā' according to nuzūl order and refer to five time prayer in its content. The starting point of this conflict between the mufassirs is based on the verb "سَّتح / glorify" mentioned in these verses. Because some of the mufassirs interpreted this verb as "صَّل / pray", some interpreted it as normal "dhikr and glorification". In this context mufassirs such as Muqātil b. Suleiman, Sufyān al-Sawrī, Tabarī, Ibn Ab̄̄ Ḥātim, Sa'labī, Māwardī, Wāḥidī, Sam’ānī, Ibn 'Atiyya, Zamakhsharī, Rāzī, Bayḍāvī have interpreted the command " س / glorify" in verses Qāf 39-40 and Ṭā Hā 130 as " صَّل / pray". It is a remarkable consideration that Muqātil b. Suleiman, who exegesis the Qur'ān from beginning to end, gave the meaning of "perform prayer" to the verb " سَِّّْْ/glorify" in these verses.

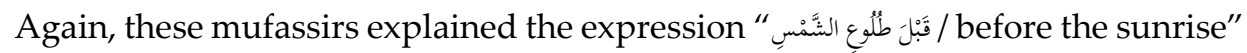
as "fajr prayer", "وَقَبْلَ الْغُرُوبِ / before the sun goes down" as "dhuhr and asr prayers" and "وَمْنَ المَِّّلِ / night hours" as "the Maghrib and 'Isha prayers" which is mentioned in these verses with some differences. Izzet Derveze also stated that the five daily prayers were obligatory before Mi ianj, based on the interpretations of the mufassirs mentioned in his work titled at-Tafsìr al-Hadīth, which he compiled based on 'Uthmān's nuzūl order. According to him, the basis of this claim is that some mufassirs interpret the times of tasbī expressed in Qāf 39-40 and Ṭā Hā 130 verses as five prayer times, based on the idea that prayer is essentially a 
M. ALTUNTAŞ / In the Light of Tafsīr Literature, Prayer (Salāt) in the Sūrahs Sent Down before the

Event of Isrā' | 61

tasbīh. Thus, according to him, performing five prayers means the same as glorifying Allah. But this claim is not accepted by some scholars, as it contradicts the Mi 'rāj incident, nor is it clarified.

Another issue causing the dispute mentioned above is the expression to أَقَمِ الصَََّاةَ

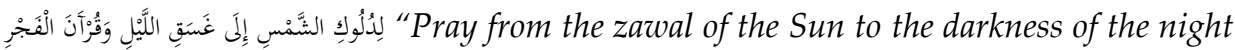
and perform the sunrise prayer", which is interpreted as dhuhr, asr, maghrib, isha and fajr prayers in the verse 78 of sūrah al-Isrā', which was sent down in the $50^{\text {th }}$ order after Qāf and TTā Hā. While the command "سَّ / glorify" in sūrahs Qāf and Țā Hā is interpreted by the mufassirs as a presumption for the five-time prayer, the corresponding "أَقَمِ الصََّاذَة / perform the prayer" command in sūrah al-Isrā' clearly indicates the five-time prayer. It should also be noted that the question of when the five times prayer begins has a broad scale that exceeds the size of an article. For, this issue has a relationship with the Qur'ān and Tafsīr, as well as Hadith and Sirah. In this article, we will focus on the words indicating the prayer and prayer times in the sūrahs that were sent down before al-Isrā'.

Keywords: Tafsīr, Qur'ān, Mecca, Prayer, Time.

\section{Tefsir Literatürü Işığında İsrâ Olayından Önce Nâzil Olan Sûrelerde Namaz Öz}

Namazın Mekke'de sabah ve akşam olmak üzere ikişer rekât kılındığına ve daha sonraları beş vakte çıkarıldığına dair hadis kitaplarında pek çok rivâyet bulunmaktadır. Genel kabul beş vakit namazın Mi'rac hadisesini anlatan rivâyet dikkate alınarak Mi'rac'dan sonra farz kılındığı yönündedir. Bununla beraber beş vakit namazın ne zaman başladığı hususunda müfessirler arasında ihtilaflar bulunmaktadır. Nüzûl tertiplerine göre İsrâ'dan önce nâzil olan Fâtiha, 'Alak, Müzzemmil, Müddessir, 'Alâ, Tîn, 'Asr, Kevser, Necm, Mâ'ûn, 'Araf, Cin, Furkân, Fâtır, Meryem, Şu'ara ve Neml Sûrelerinde namaz ibâdeti zikredilmesine rağmen bu sûrelerde namazın vakitleri konusunda doğrudan bir kelime bulunmamaktadır. Sadece bazı müfessirler 'Asr sûresindeki "asr" kelimesini ikindi namazı vakti olarak yorumlamışlardır.

Namazın beş vakit olarak Mi'rac'dan önce mi yoksa sonra mı başladığı konusundaki ihtilaflar, nüzûl tertiplerine göre İsrâ sûresinden önce nâzil olan ve muhtevasında beş vakit namaza işaret eden Kâf 39-40 ve Tâhâ 130. âyetlerinin tefsiri bağlamında şekillenmektedir. Müfessirler arasındaki bu ihtilafın çıkış 
62 | M. ALTUNTAŞ / Tefsir Literatürü Işı̆̆ğnda İsrâ Olayından Önce Nâzil Olan Sûrelerde Namaz noktası bu âyetlerde geçen “سَّ / tesbîh et” fiiline dayanmaktadır. Zîra bu fiili müfessirlerin bir kısm1 "صَّل / namaz k1l” olarak tefsir ederken bir kismı da normal "zikir ve tesbîh" olarak yorumlamıştır. Bu bağlamda Mukâtil b. Süleymân, Süfyân es-Sevrî, Taberî, İbn Ebî Hâtim, Semerkandî, İbn Ebî Zemenîn, Sa'lebî, Mâverdî, Vâhidî, Sem'ânî, İbn 'Atiyye, Zemahşerî, Râzi, Beydâvî gibi müfessirler

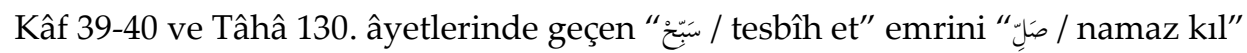
şeklinde tefsir etmişlerdir. Bu müfessirlerden Kur'ân'1 baştan sona tefsir eden

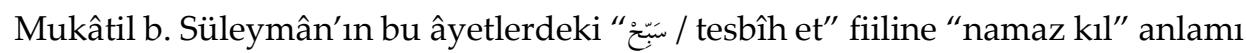
vermiş olması dikkate değer bir husustur.

Yine bu müfessirler bazı farklılıklarla bu âyetlerde geçen “ قَبْلَ طُلؤع الشَّمْسِ / güneş

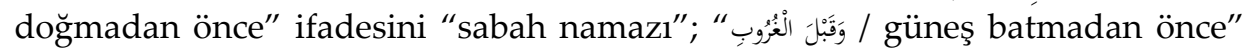

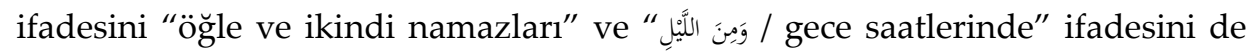
"akşam ve yatsı namazları" olarak açıklamışlardır. İzzet Derveze de Hz. Osmân'ın nüzûl tertibini esas alarak telif ettiği et-Tefsîru'l-Hadîs adlı eserinde zikredilen müfessirlerin yorumları üzerinden beş vakit namazın Mi'rac'dan önce farz kılındığına dair görüş belirtmiştir. Ona göre bu iddianın temeli; namazın özünde bir tesbîh olduğu düşüncesinden hareketle bazı müfessirlerin Kâf 39-40 ve Tâhâ 130. âyette ifade edilen tesbîh vakitlerini beş vakit namaz olarak yorumlamalarıdır. Dolayısıyla ona göre beş vakit namazı kılmak Allah'1 tesbîh etmekle aynı anlama gelmektedir. Ancak bu iddia, Mi'rac hadisesiyle çeliştiği için bazı âlimler tarafından kabul görmediği gibi tam olarak da açıklığa kavuşmuş değildir.

Söz konusu ihtilafa sebep olan bir başka husus da Kâf ve Tâhâ'dan sonra 50 . sırada nâzil olan İsrâ sûresinin 78. âyetinde öğle, ikindi, akşam, yatsı ve sabah namazları olarak yorumlanan Güneşin zevalinden gecenin karanlığına kadar namazı kıl. Bir de sabah namazını kıl" ifadesidir. Kâf ve Tâhâ sûrelerindeki “ “سّن / tesbîh et” emri müfessirler tarafından beş vakit namaz için bir karîne olarak tefsir edilirken buna mukâbil İsrâ

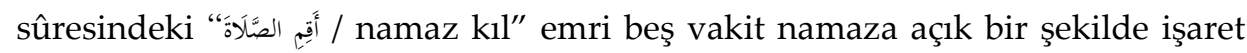
etmektedir. Şunu da ifade etmek gerekir ki beş vakit namazın ne zaman başladı̆̆ı konusu bir makalenin boyutunu aşacak nitelikte bir genişliğe sahiptir. Zira bu konunun Kur'ân ve tefsirlerin yanı sıra hadis ve siyerle de ilişkisi bulunmaktadır. $\mathrm{Bu}$ makalede İsrâ'dan önce nâzil olan sûrelerde geçen namaz ve namaz vakitlerine işaret eden kelimeler üzerinde durulacaktır.

Anahtar Kelimeler: Tefsir, Kur'ân, Mekke, Namaz, Vakit. 
M. ALTUNTAŞ / In the Light of Tafsīr Literature, Prayer (Salāt) in the Sūrahs Sent Down before the

Event of Isrā' | 63

\section{Giriş}

"Salât" kelimesi lafzî olarak Medenî olan Tevbe 99 ve Ahzâb 43 ile 56. âyetlerinde "dua ve bereket" anlamina gelmektedir. Ancak bu kelimeye "namaz" anlamının verilmesi, Enfâl 35. âyette de işaret edildiği üzere İslâm'dan öncesine dayanmaktadır. Bakara 125 ve Hacc 26. âyetlerde Hz. İbrâhîm ve Hz. İsmâîl'e hitâben Kâ'be'nin tavaf, rükû ve secde edenler için temizlenmesi emri, "salât" kelimesinin bu manasının müssrikler tarafından bilindiğini ortaya koymaktadır. ${ }^{1}$ Salât, mü'minin yardım esnasında sabırla beraber başvuracağı iki amelden biridir. ${ }^{2}$ Ayrıca önemine binâen salât Kur'ân'da en zor zamanlar olarak geçen savaş/düşmandan korkma anında bile edâ edilmesi gereken bir ibâdet olarak karşımıza çıkmaktadır. ${ }^{3}$

Ayrıca dinin direğini teşkil eden ve Mekkî sûrelerde de yer alan salât: “Onları, emrimizle doğru yolu gösteren önderler yaptık. Kendilerine hayırlı işler yapmayı, namazı dosdoğru kılmayı, zekâtı vermeyi vahyettik. Onlar yalnız bize ibadet eden kullardı" 4 âyetine ilaveten Meryem 55, Tâhâ 14, Beyyine 5. âyetlerde belirtildiği üzere zekâtla beraber peygamberlere emredilen iki temel ibadetten biri olarak karşımıza çıkmaktadır. Diğer taraftan salât, Kur'ân'da zekâtla beraber kişiyi felâha/cennete erdiren iki amelden biri olarak sunulmaktadır. ${ }^{5}$

"Şüphesiz namaz, mü'minlere belirli vakitlerde farz kılınmıştır". ${ }^{6}$ Ancak namazın beş vakit olarak ne zaman başladığı konusunda âlimler arasında genel olarak iki görüş bulunmaktadır. Buna göre bazı âlimler hadislere istinâden beş vakit namazın İsrâ ve Mi'rac'dan sonra başladığını ve İsrâ gecesi başta elli vakit olarak belirlenen namazın beş vakte düşürüldügünü söylemektedirler.7 Buna mukâbil İbn Hişâm (öl.

1 Muhammed 'İzzet Derveze, et-Tefsîru'l-hadîs (Kâhire: Dâru İhyâi'l-Kütübi'l-'Arabiyye, 1383), 1/327-328.

2 el-Bakara 2/45, 153.

3 el-Bakara 2/238-239; en-Nisâ 4/101.

4 el-Enbiyâ 21/73.

5 el-'Alâ 87/14-15.

6 en-Nisâ 4/103.

7 Hadis için bk. Ebû 'Abdillâh Muhammed b. İsmâ'îl el-Buhârî, Sahîhu'l-Buhârî (İstanbul: Çağrı Yayınları, 1992), "Salât”, 1; Ebû'l-Hüseyn Müslim b. el-Haccâc el-Kuşeyrî, Sahîh (İstanbul: Çağrı Yayınları, 1992), “Îmân”, 74; Ebû 'Abdirrahmân Ahmed b. Şua'yb en- 
218/833) "namazın farz kılınışının başlaması" başlığı altında namazların başlangıçta ikişer rekât olarak farz kılındığını, sonra mukîm olanlar için dört ve seferî olanlar için tekrar ikişer rekât olarak belirlendiğini söylemektedir. ${ }^{8}$ Yine o, İbn İshâk'tan (öl. 151/768) rivâyetle Cebrâil'in, Mekke'nin en yüksek noktasında iken Hz. Peygamber' in yanına gelerek ona abdest almayı öğrettiğini nakletmektedir. ${ }^{9}$ Bununla beraber İbn Hişâm; İbn İshâk'ın, İ̉nn 'Abbâs'tan (öl. 68/687-88) beş vakit namazın ne zaman kılınacağı konusunda bir zaman belirtmeksizin şöyle bir hadis naklettiğini belirtmektedir:

\footnotetext{
“Namaz farz kılındığında Cebrâîl (a.s), Hz. Peygamber'in yanına gelip güneş batıya meylettiğinde öğle, eşyanın gölgesi iki misli olunca ikindi, güneş battığında akşam, şafak kaybolduğunda yatsı, fecir doğduğunda sabah namazını kıldırdı. İkinci gün öğleyi güneşin gölgesi misli kadar olduğunda; ikindiyi, her şeyin gölgesi kendisinin iki misli olunca; akşamı, yine önceki günün vaktinde; yatsıyı, gecenin üçte biri geçince; sabahı, güneş doğmadan ortalık ağarınca kıldırdı ve sonra şöyle dedi: 'Ey Muhammed! Senin kılacağın namaz dün ve bugünkü vakitler arasındadır'”. 10
}

Mukâtil (öl. 150/767) de buna benzer bir rivâyeti Duhâ sûresi 11. âyet bağlamında nakletmektedir. ${ }^{11}$

Beş vakit namazın ne zaman başladığı konusunda âlimler arasındaki ihtilafı açıklığa kavuşturmak için; makalemizde Derveze'nin (1888-1984) Hz. Osmân'a nispet edilen nüzûl tertibini esas alan etTefsîru'l-Hadîs adlı eserini esas alacak; İsrâ' dan önce nâzil olan sûrelerdeki namaz ve namaz vakitlerine işaret eden kelimeleri inceleyeceğiz. Böylece Mekke döneminde namazın kaç vakit olduğunu ve ne zaman kılınmaya başladığını tespit etmeye çalışacağız. Bir başka ifadeyle Derveze'nin beş vakit namazın İsrâ ve Mi'rac'dan önce var olduğu iddiasının doğru olup

Nesâî, Sünen (İstanbul: Çağrı Yayınları, 1992), "Salât", 1; Ebû 'Abdillâh Muhammed b. Yezîd Mâce el-Kazvînî, Sünen (İstanbul: Çağrı Yayınları, 1992), "İkâmetu's-salât”, 194.

8 Ebû Muhammed Cemâlüddîn 'Abdülmelik b. Hişâm, es-Sîretu'n-nebeviyye, thk. Mustafâ eş-Şekkâ vd. (Beyrut: Dâru'l-Hayr, 1995), 1/195.

9 İbn Hişâm, es-Sîretu'n-nebeviyye, 1/196.

10 İbn Hişâm, es-Sîretu'n-nebeviyye, 1/197. Ayrıca namaz vakitleri için bk. Ebû 'Îsâ Muhammed b. 'Îsâ b. Sevre et-Tirmizî, Sünen (İstanbul: Çağrı Yayınları, 1992), "Salat”, 1; Süleyman b. el-Eşa's Ebû Dâvûd, Sünen (İstanbul: Çağrı Yayınları, 1992), "Salât", 2.

11 Ebu'l-Hasen Mukâtil b. Süleymân b. Beşîr el-Ezdî el-Belhî, Tefsîru Mukâtil b. Süleymân, thk. Ahmed Ferîd (Beyrut: Dâru'l-Kütübi'l-'Illmiyye, 2003), 3/495. 
M. ALTUNTAŞ / In the Light of Tafsīr Literature, Prayer (Salāt) in the Sūrahs Sent Down before the Event of Isrā' | 65

olmadığını araştıracağız. Bizi bu araştırmaya sevk eden husus Derveze'nin beş vakit namaz konusundaki şu sözleridir:

"İsrâ sûresinden önce nâzil olan Kâf ve Tâhâ sûrelerinde bazı âyetler vardır ki, bazı müfessirler bu âyetlerde beş vakit namaz ve bunların vakitlerinin anlatıldığını söylemişlerdir. Bunlar Kâf 39-40 ve Tâhâ 130. âyetlerdir" ${ }^{12}$

$\mathrm{Bu}$ çalışmanın özünü bütün nüzûl tertiplerinde ${ }^{13}$ İsrâ sûresinden önce nâzil olan Kâf sûresinin 39-40 ve Tâhâ sûresinin 130. âyetleri oluşturmaktadır. Zira pek çok müfessire göre bu âyetlerdeki "tesbîh et" emri ve bu bağlamdaki zamanla ilgili kelimeler, bir karîne olarak, beş vakit namaza işaret etmektedir. Fakat bu âyetlerden önce nâzil olan ve namaza işaret eden kelimelerin incelenmesi ve müfessirlerin görüşlerinin ortaya konulması konunun daha iyi anlaşılmasına katkı sağlayacaktır.

\section{Fâtiha, 'Alak, Müzzemmil, Müddessir, 'Alâ, Tîn, 'Asr, Kevser, Necm ve Mâ'ûn Sûreleri}

Fâtiha'yı ilk tam nâzil olan sûre olarak kabul eden Derveze, bunun hikmetini onun namazın her rekâtında okunmasına bağlamaktadır. ${ }^{14}$ İlk nâzil olan sûreler arasında yer alan 'Alak sûresinin 9-10. âyetlerinde

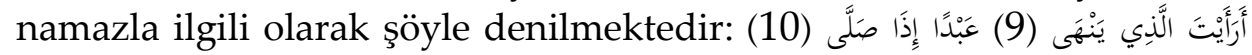
“Namaz kıldığı zaman, bir kulu engelleyeni gördün mü?" Derveze, 'Alak sûresinin 10. âyetini açıklarken "salât" kelimesinin "dua" anlamının yanında bilinen şekliyle bir ibâdet olarak baştan beri var olduğunu ifade etmektedir. Zira 'Alak sûresinin 9-10. âyetleri, davetin gizli olarak başladığını söyleyen rivâyetlerin aksine açık bir şekilde başladığını, Hz. Peygamber'in âyetleri insanlara okuyup onları müjdeleyip uyardığını, namaza devam ettiğini ve Ebû Cehil'in (öl. 2/624) Hz. Peygamber'i namazdan alıkoyma girişimlerini anlatmaktadır. ${ }^{15}$ Mukâtil de bu âyet bağlamında namazın Mekke' de erken dönemlerde farz kılındığını ve Ebû Cehil'in “Eğer Muhammed'i namaz kılarken görürsem boynunu

12 Derveze, et-Tefsîru'l-hadîs, 2/250.

13 Muhtelif nüzûl tertipleri için bk. Mustafa Öztürk - Hadiye Ünsal, Kur'ân Tarihi (Ankara: Ankara Okulu Yayınları, 2016), 258-318.

14 Derveze, et-Tefsîru'l-hadîs, 2/285.

15 Derveze, et-Tefsîru'l-hadîs, 2/323-324. 
66 | M. ALTUNTAŞ / Tefsir Literatürü Işı̆̆ında İsrâ Olayından Önce Nâzil Olan Sûrelerde Namaz vuracağım" dediğini nakletmektedir. ${ }^{16}$ Ancak o, bu namazın kaç vakit olduğu konusunda herhangi bir bilgi vermemektedir.

Müzzemmil sûresinin 1-8 ve $20 .{ }^{17}$ âyetlerinde Hz. Peygamber'e gecenin bir kısmında teheccüd namazı kılması ve Kur'ân okuması emredilmektedir. Mukâtil, gece namazının Mekke'de beş vakit namaz farz kılınmadan önce var olduğunu, Hz. Peygamber ve mü'minlerin bir sene boyunca bu namaza devam ettiklerini ancak bu onlara ağır gelince bir y1l sonra inen 20. âyetle bu hükmün Hz. Peygamber için devam edip mü'minlerden kaldırıldığını ve bunun yerine beş vakit namazın farz kılındığını söylemektedir. ${ }^{18}$ Ancak Mukâtil buradaki bir yıllık zamanı neye göre belirlediği konusunda herhangi bir bilgi vermemektedir.

Ferrâ (öl. 207/822) ve Semerkandî (öl. 373/983) Müddessir sûresinin

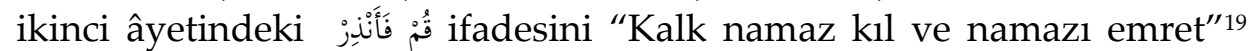

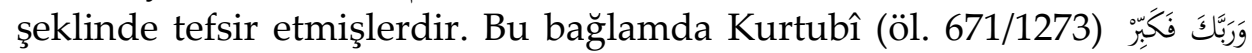
"Rabbini yücelt"20 âyetinin ashabın "namaza nasıl başlanılır" sorusu üzerine indiğini söylemektedir. Bu âyet inince Hz. Peygamber "Allâhu ekber" diye tekbir getirince Hz. Hatice de bunu tekrar etmiştir. ${ }^{21}$ Ayrıca Müddessir sûresinin 42-43. âyetlerinde kafirlerin sekar'a/alevli ateşe girmelerinin birinci nedeni namaz kılmama olarak açıklanmaktadır. İlgili

16 Mukâtil b. Süleymân, Tefsîru Mukâtil b. Süleymân, 3/501.

17 Derveze'nin naklettiğini göre Nisâbûrî, Âlûsî, Hâzin ve Tabresî bu âyetin Medîne'de nâzil olduğunu söylemektedirler. Bk. Derveze, et-Tefsîru'l-hadîs, 1/426. Ayrıca bk. Nizâmuddîn el-Hasen b. Muhammed b. el-Hüseyn el-Kummî en-Nîsâbûrî, Garâibu'lKur'ân, thk. Zekeriyyâ 'Umeyrât (Beyrut: Dâru'l-Kütübi'l-'Illmiyye, 1416), 6/382; Şihâbüddîn Mahmûd b. 'Abdillâh el-Hüseynî el-Âlûsî, Rûhu'l-me'ânî, thk. 'Abdulbârî 'Atiyye (Beyrut: Dâru'1-Kütübi'l-'İlmiyye, 1415), 15/126; 'Alâüddîn 'Alî b. Muhammed b. İbrâhîm el-Hâzin, Lubâbu't-te'vîll, thk. Muhammed 'Alî Şâhîn (Beyrut: Dâru'lKütübi'l-'Illmiyye, 1415), 4/355.

18 Mukâtil; Müzzemmil sûresindeki bu namazın beş vakit namazın farz kılınışından önce olduğunu söylemektedir. Bk. Mukâtil b. Süleymân, Tefsîru Mukâtil b. Süleymân, 3/409, 411-412.

19 Ebû Zekeriyyâ Yahyâ b. Ziyâd b. 'Abdillâh b. Manzûr ed-Deylemî el-Ferrâ, Me'âni'lKur'ân, thk. Ahmed Yûsuf en-Necâtî vd. (Misır: Dâru'1-Misriyye, ts.), 3/200; Ebü'1-Leys Nasr b. Muhammed b. Ahmed b. İbrâhîm es-Semerkandî, Bahru'l-'ulûm (b.y.: y.y., ts.), $3 / 514$.

20 el-Müddessir 74/3.

21 Ebû 'Abdillâh Muhammed b. Ahmed el-Ensârî el-Kurtubî, el-Câmiu' li ahkâmi'l-Kur'ân (Beyrut: Dâru'l-Fikr, 1995), 19/58-59. 
M. ALTUNTAŞ / In the Light of Tafsīr Literature, Prayer (Salāt) in the Sūrahs Sent Down before the

Event of Isrā' | 67

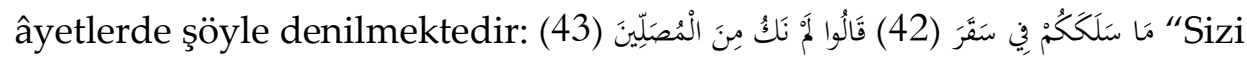
yakıcı ateşe ne sürükledi? Dediler ki: 'Biz namaz kılanlardan olmadik.'” İlk nâzil olan sûrelerden biri olan Müddessir'de geçen bu ifadeler, namazın erken dönemlerden beri var olduğunu gösteren başka bir delildir. Bununla beraber bu âyetlerde namazın kaç vakit olduğu hususunda bir ifade geçmemektedir. Diğer taraftan benzer bir ifade de Kıyâme sûresi 31. âyette geçmektedir. Müfessirler bu âyetteki " وَلَالَ صَلَّى / ve namaz kılmadı" ifadesinin Ebû Cehil hakkında nâzil olduğunu söylemektedirler. ${ }^{22}$ Erken dönemlerde nâzil olan bu iki âyette cehenneme girmenin ana nedenlerinden biri olarak "namazların kılınmama" hususunun zikredilmesi dikkate şayandır. Müddessir sûresi bağlamında değinilmesi gereken bir başka husus da Tahir Olgun'un görüşüdür. Zira o, Müddessir sûresinin ilk âyetleri bağlamında namazın başlaması konusunda şöyle demektedir:

“Bazı kitapların mütalaasından benim anlayışıma göre aleyhissalâtü vesselâm efendimiz

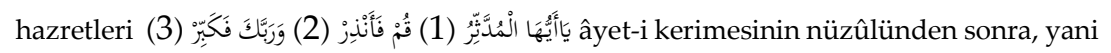
takriben kırk üç yaşlarında iken Cebrâil'in tarifi ile abdest alıp namaz kılmış, sonra Hadicetü'l-Kübrâ radiyellahu anhaya da abdest aldırıp namaz kıldırmıştır" ${ }^{23}$

Diğer taraftan 'Alâ 14-15. âyetlerde "Zekâtını veren, Rabbinin adını anarak namaz kılan felâha ermiştir" denilmektedir. Derveze namaz ve zekâtın pek çok âyette beraber kullanılmasından hareketle 14. âyetteki "tezekkî" ifadesini "teşvik ve özendirme" bağlamında "malın zekâtı" anlamında yorumlamış diğger taraftan bu "teşvik ve özendirmenin" namaz için de geçerli olduğunu ve her ikisinin risâletin başından beri var olduğunu söylemiştir. Ayrıca o, zekât ve namazın ilk mü'minler için bir

22 Mukâtil b. Süleymân, Tefsîru Mukâtil b. Süleymân, 3/423; Ebû Ca'fer Muhammed b. Cerîr et-Taberî, Câmiu'l-beyân, thk. Sıdkı Cemîl el-'Attâr (Beyrut: Dâru'l-Fikr, 2001), 14/8727; Ebû Muhammed 'Abdurrahmân b. Muhammed b. İdrîs er-Râzî İbn Ebî Hâtim, Tefsîru'l-Kur'âni'l-'azîm, thk. Es'ad Muhammed et-Tayyib (Arabistan: Mektebetü Nizâr Mustafa el-Bâz, 1419), 10/3389; Kurtubî, el-Câmiu' li ahkâmi'l-Kur'ân, 19/102.

23 Tahir Olgun, Müslümanlıkta İbâdet Tarihi (Ankara: Akçă̆ Yayınları, 1998), 50-51. 
68 | M. ALTUNTAŞ / Tefsir Literatürü Işı̆̆ında İsrâ Olayından Önce Nâzil Olan Sûrelerde Namaz "emir ve bağlayıcılık" olmasında da bir engel olmadığını ifade etmektedir. ${ }^{24}$

İçinde namazla ilgili doğrudan herhangi bir ifade olmasa da Tin 78. âyetleri sabah namazıyla ilişkilendiren Mukâtil bu âyetler hakkında şöyle demektedir: "Ey Muhammed; kırâat, rükû, secde, teşehhüdün ardından farz namazı bitirmeden önce oturuyorken duâ ile O'ndan talepte bulun". ${ }^{25}$ Yine Mukâtil, Duhâ 11. âyet hakkında namaz ve abdest bağlamında şu bilgileri nakletmektedir:

“Cibrîl, Mekke'nin üst taraflarında iken Nebî'nin yanına gelip elleriyle toprağı itti ve oradan bir pınar fışkırdı. Cibrîl, bu pınardan Nebî’ye öğretmek amacıyla abdest aldı. Ardından Nebî de abdest aldı ve Cibrîl ona namaz kıldırdı. Cibrîl gittikten sonra Nebî bunları Hatice'ye öğretti ve birlikte namaz kıldılar" ${ }^{26}$

Süleyman Ateş ise hangi ibâdet olduğuna dâir bir belirleme yapmaksızın bu âyetlerde dünyevî işlerden sonra Hz. Peygamber'e ibâdetin emredildiğini söylemektedir. ${ }^{27}$

Müfessirlerin bir kısmı 'Asr sûresinin birinci âyetindeki "'asr" kelimesinin mutlak anlamda $\operatorname{zaman}^{28}$ ve ikindi namazi ${ }^{29}$ anlamina geldiğini belirtmişlerdir. Kur'ân bağlamında şimdiye kadar ele aldığımız âyetlerde ilk defa, ihtilaflı olmakla beraber, bir namaz vaktine yani ikindi namazına vurgu yapılmaktadır. İkindi namazı Bakara 238. âyette "salâtu'l-vustâ"30 olarak da geçmektedir. Dolayısıyla zamana/ikindi

24 Bk. Derveze, et-Tefsîru'l-hadîs, 1/517-518; Ali Binol, “Kur'ân'da Geçen Tezekkî Kavramı Üzerine Bir Değerlendirme”, Bozok Üniversitesi İlahiyat Fakültesi Dergisi 11/11 (Haziran 2017), 185-206.

25 Mukâtil b. Süleymân, Tefsîru Mukâtil b. Süleymân, 3/497.

26 Mukâtil b. Süleymân, Tefsîru Mukâtil b. Süleymân, 3/495.

27 Süleyman Ateş, Yüce Kur'ân'ın Çă̆daş Tefsiri (İstanbul: Yeni Ufuklar Neşriyat, 1990), $10 / 527$.

28 Ebû Muhammed 'Abdullâh b. Müslim b. Kuteybe ed-Dîneverî, Garîbü'l-Kur'ân, thk. Sa'îd el-Lihâm (b.y.: y.y., ts.), 469; Ebû 'Abdillâh Muhammed b. 'Abdillâh b. 'Îsâ İbn Ebî Zemenîn, Tefsîru'l-Kur'âni'l-'azîz, thk. Ebû 'Abdillâh Hüseyin b. 'Ukkâşe Muhammed b. Mustafâ el-Kenz (Misır: el-Fârûku'-l-Hadîse, 2002), 5/161.

29 Mukâtil b. Süleymân, Tefsîru Mukâtil b. Süleymân, 3/516; Semerkandî, Bahru'l-'ulûm 3/615; Derveze, et-Tefsîru'l-hadîs, 1/562.

30 Râzî, âlimlerin "salâtu'l-vustâ" ifadesinin sabah, öğle, ikindi, akşam ve yatsı olmak üzere bütün namazları içerdiğini söylediklerini nakletmektedir. Ona göre de bu ifadenin tüm namazlara hamledilmesi gerekmektedir. Bk. Ebû 'Abdillâh Muhammed 
M. ALTUNTAŞ / In the Light of Tafsīr Literature, Prayer (Salāt) in the Sūrahs Sent Down before the

Event of Isrā' | 69

namazına yemin edilerek sûreye başlanması en azından bir kısım müfessirlere göre bu sûre indiğinde veya öncesinde ikindi namazının kılındığına işaret etmektedir.

Kevser sûresinin 1. âyetinde Hz. Peygamber'e “kevser' in" verilmesi karşılığında 2. âyette فَصَّلَ لِربِّكَ وَانْرَ namaz kilması ve kurban kesmesi emredilmektedir. Ancak burada hangi namazların kılınmasının istendiği vakit olarak belirtilmemiştir. ${ }^{31}$ Buna rağmen Mukâtil burada kastedilenin beş vakit namaz olduğunu söylemektedir.32 $\mathrm{Bu}$ âyette hangi namazın kastedildiği konusunda âlimlerin ihtilaf ettiğini söyleyen Taberî ise (öl. 310/923), İbn 'Abbâs (öl. 68/687-88) dişında isim vermeden bazılarının bunun beş vakit; Sa'îd b. Cübeyr (öl. 94/713 [?]), Haccâc (öl. 145/762) ve İbn 'Atiyye'nin (öl. 111/729-30) sabah; Rebî' (öl. 65/685 [?]) ve Katâde'nin (öl. 117/735) kurban bayramı namazı olduğunu söylediklerini nakletmektedir. ${ }^{33}$

Necm 62. âyetteki فَانْجُدُوا لِلَّهِ وَاعْبُدُوا "Allah'a secde ve kulluk edin." hitâbının hem kâfirlere hem de mü'minlere yönelik olmasının ihtimal dahilinde olduğunu söyleyen Derveze, bununla Allah'a secde ve ibâdet edilmesi gerektiğini söylerken ${ }^{34}$ Mukâtil bu ifadeyi "beş vakit namaz kılın" şeklinde tefsir etmiştir. ${ }^{35}$

Müslümanların kıldığı namazla ilgili olmasa da Mâ'ûn sûresinin 46. âyetleri müşriklerin gösteriş için kıldıkları namazlardan bahsetmektedir. Bu sûrede geçen "ماة / مُصَلِينَ" / namaz" ve / naz kılanlar" kelimeleri, bu ibâdeti çarpıtmış olsalar da müşriklerin buna vâkıf olduklarını göstermektedir. Ayrıca Enfâl 35. âyette kısa da olsa müşriklerin Kâ'be'de ıslık çalıp el çırparak kıldıkları namazdan bahsetmektedir. Mukâtil ve bazı müfessirler yukarıda geçtiği üzere bu sûrelerin bir kısmı bağlamında beş vakit namazın farz kılındığını söyleseler de "ihtilaflı olan 'Asr sûresindeki ikindi namazı" hariç, bu

b. 'Ömer Fahruddîn er-Râzî, Mefâtîhu'l-gayb (Beyrut: Dâru İhyâi't-Türâsi'l-'Arabî, 1420), 6/483-487.

31 Derveze, et-Tefsîru'l-hadîs, 2/11-12.

32 Mukâtil b. Süleymân, Tefsîru Mukâtil b. Süleymân, 3/528.

33 Taberî, Câmiu'l-beyân, 15/8879-8881.

34 Derveze, et-Tefsîru'l-hadîs, 2/119.

35 Mukâtil b. Süleymân, Tefsîru Mukâtil b. Süleymân, 3/295. 
70 | M. ALTUNTAŞ / Tefsir Literatürü Işı̆̆ında İsrâ Olayından Önce Nâzil Olan Sûrelerde Namaz sûrelerde namazın kaç vakit olduğuna dâir lafzî olarak herhangi bir bilgi bulunmamaktadır.

\section{Kâf Sûresi 39-40. Âyetler}

Hz. Osmân'ın mushaf tertibine göre 34. sırada nâzil olan Kâf sûresinin ne zaman indiğine dair sağlam rivâyetler olmadığını söyleyen Mevdûdî (öl. 1979) muhtemelen bu sûrenin risâletin üçüncü ve beşinci yılları arasında nâzil olduğunu belirtmektedir. ${ }^{36}$ " "َّبّ / tesbîh et" emrinden hareketle müfessirlerin bir kısmına göre Mekkî sûrelerde "beş vakit namaz" bağlaminda ilk ifadeler Mürselât'tan sonra nâzil olan Kâf sûresinin 39-40. âyetlerinde geçmektedir. Bu âyetlerdeki "güneşin doğuşundan önce", "güneşin batışından önce", "gecenin bir kısmında" ve "secdelerin ardından" ifadelerinin hangi namazları belirttiğ $i$ konusunda farklı görüşler ileri sürmüşlerdir. Bununla beraber onların bu bağlamdaki açıklamaları dikkate alındığında bu ifadelerin beş vakit namaza işaret ettiği anlaşılmaktadır. Müfessirlerin bu âyetler hakkındaki görüşlerine geçmeden önce ilgili âyetlerin metnini ve meâlini vermek yararlı olacaktır.

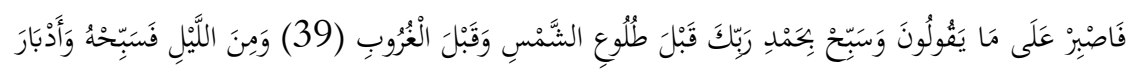

(40) "Onların söylediklerine sabret; Rabbini güneşin doğuşundan ve batışından önce hamd ile tesbîh et. Gecenin bir kısmında ve secdelerin ardında da O'nu tesbîh et". ${ }^{37}$

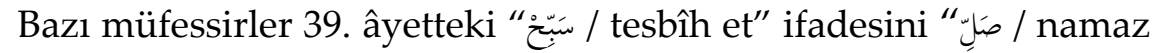
kıl” şeklinde tefsir etmiştir. ${ }^{38}$ Mukâtil ve Ebüssuûd Efendi (öl. 982/1574), "güneşin doğuşundan önce" ifadesinin sabah, "güneşin batışından önce" ifadesinin öğle ve ikindi; "gecenin bir kısmında" ifadesinin akşam ve yatsı ve "secdelerin ardından" ifadesini de akşam namazından sonra

36 Ebü'l-A'lâ Mevdûdî, Tefhîmu'l-Kur'ân, çev. Muhammed Han Kayanî vd. (İstanbul: İnsan Yayınları, 1996), 5/467.

37 Kâf 50/39-40.

38 Bk. Mukâtil b. Süleymân, Tefsîru Mukâtil b. Süleymân, 3/273; Ferrâ, Me'âni'l-Kur'ân, 3/80; Taberî, Câmiu'l-beyân, 13/7985; İbn Ebî Hâtim, Tefsîru'l-Kur'âni'l-'azîm, 10/3310. Buna mukâbil Kuşeyrî bu ifadeyi normal tesbîh anlamında açıklamıştır. Bk. 'Abdülkerîm b. Hevâzin b. 'Abdilmelik el-Kuşeyrî, Letâifü'l-işârât, thk. İbrâhîm el-Besyûnî (Mısır: elHey'etü'l-Misriyyetü'l-'Âmme li'l-Kitâb, ts.), 3/457. 
M. ALTUNTAŞ / In the Light of Tafsīr Literature, Prayer (Salāt) in the Sūrahs Sent Down before the

Event of Isrā' | 71

kılınan iki rekâtlık nâfile namaz olarak açıklamıştır. ${ }^{39}$ Buna karşın Taberî; Katâde ve İbn Zeyd'den nakille "güneşin doğuşundan önce” ifadesini sabah, "güneşin batışından önce" ifadesini ikindi ve "gecenin bir kısminda" ifadesini yine İbn Zeyd'den nakille yatsı namazı olarak açıklamıştır. ${ }^{40}$ Bununla beraber Taberî, "gecenin bir kısmında" ifadesinin gecenin tamamını kapsadığını söyleyen Mücâhid'in (öl. 103/721) görüşünü baz alarak bu ifadenin akşam ve yatsı namazı olarak tefsir edilmesinin daha doğru olduğunu söylemiştir. ${ }^{41}$ Yine Taberî "secdelerin ardından” ifadesini Hz. Alî (öl. 40/661), Ebû Hüreyre (öl. 58/678), Şa'bî (öl. 104/722) ve Mücâhid'den nakille akşamdan sonra kılınan iki vakit nâfile namaz olarak açıklamıştır. Kurtubî ise isim vermeden bazı âlimlerin sadece "güneşin doğuşundan ve batışından önce Rabbini tesbîh et" ifadesini beş vakit namaz olarak açıkladıklarını ifade etmiştir. Diğger taraftan o, Ebû Sâlih'in (öl. 101/719-20) bu ifadeyi Cerîr b. 'Abdullâh'ın (öl. 51/671) rivâyet ettiği merfû bir hadise istinâden sabah ve ikindi namazları olarak açıkladığını söylemektedir. Yine o İbn 'Abbâs'ın "güneşin batışından önce" ifadesini öğle ve ikindi, "gecenin bir kısmında" ifadesini ise akşam ve yatsı namazı olarak açıkladı̆̆ını belirtmektedir.42 Ayrıca Kurtubî "gecenin bir kısmında ve secdelerin arkasında O'nu tesbîh et" ifadesinin âlimler tarafından: 1. Geceleyin Allah'in tesbîh edilmesi, 2. Gecenin herhangi bir diliminde namaz kılınması, 3. Sabah namazının iki rekâtı, 4. Yatsı namazı olmak üzere dört şekilde açıklandı̆̆ını nakletmiştir. ${ }^{43}$

Kâf 39-40. âyetlerdeki “ “سَِّّْ / tesbîh et” hitabının Hz. Peygamber'in şahsına münhasır olsa da bütün Müslümanları kapsadığını söyleyen Mâverdî ise "güneşin doğuşundan ve batışından önce Rabbini tesbîh et" ifadesini Ebû Sâlih'ten rivâyetle sabah ve ikindi; "gece saatlerinde"

39 Bk. Mukâtil b. Süleymân, Tefsîru Mukâtil b. Süleymân, 3/273; Ebûssuûd Muhammed b. Muhammed b. Mustafâ el-'İmâdî, İrşâdu'l-'akli's-selîm (Beyrut - Lübnân: Dâru İhyâi'tTürâsi'l-'Arabî, 2010), 7/454.

40 Taberî, Câmiu'l-beyân, 13/7985-7986.

41 Taberî, Câmiu'l-beyân, 13/7986.

42 Kurtubî, el-Câmiu' li ahkâmi'l-Kur'ân, 17/23-24.

43 Kurtubî, el-Câmiu' li ahkâmi'l-Kur'ân, 17/24-25. Ayrica bk. Ebü'l-Hasen 'Alî b. Muhammed b. Habîb el-Mâverdî, en-Nüket ve'l-'uyûn (Beyrut - Lübnân: Dâru'lKütübi'l-'Illmiyye, 2012), 5/357. 

ifadesini Ebu'l-Ahvas'tan rivâyetle geceleyin tesbîh, Mücâhid'den nakille gece namazı, İbn 'Abbâs'tan nakille iki rekât sabah namazı ve İbn Zeyd'den nakille yatsı namazı olarak açıklamıştır. ${ }^{44}$ Yine o, "secdelerin ardından" ifadesini Ebu'l-Ahvas'tan nakille namazlardan sonraki tesbîh, İbn Zeyd'den nakille farzlardan sonra kılınan nâfile namazlar, Hz. Alî ve Ebû Hüreyre'den nakille de akşamdan sonra kılınan iki rekât namaz olarak izah etmiştir. Ayrıca o, İbn 'Abbâs'tan nakille "edbâra's-sücûd" ifadesini ise sabah namazından önce kılınan iki rekâtlık namaz olarak tefsir etmiştir. ${ }^{45}$ Mâverdî’nin bu açıklamaları, diğer müfessirlerin ileri sürdüğü beş vakit farz namazın aksine iki vakit farz namaz olduğunu göstermektedir. "سَّ / tesbîh et" ifadesinin hem "zikir" hem de "salât/namaz" manasına gelmesinin mümkün olduğunu söyleyen Zemahşerî (öl. 538/1144) ise bu ifadelerle tesbîhle beraber beş vakit namazın da anlatıldığını söylemiştir. ${ }^{46}$

Derveze de bu âyetlerle ilgili benzer açıklamalarda bulunmuştur. $\mathrm{O}$, bu konuda isim vermeden özetle şöyle demektedir: Bazı müfessirler 39-40. âyetlerin Hz. Peygamber'e Rabbini tesbîhle hamd etmeyi emrettiğini belirtmektedir. Bununla beraber tesbîh, beş vakit namazı da içermektedir. Zira Allah'1 zikretmek; Hûd 114, İsrâ 78-79 ve Tâhâ 130. âyetlerinde belirtildiği üzere Kur'ân okumayı ve namaz kılmayı da içine almaktadır. Bu yorum doğru kabul edildiğinde bi'set'ten kısa bir süre sonra Hz. Peygamber'in ve mü'minlerin gündüz ve gecenin değişik saatlerinde namaz kıldıkları anlaşılmaktadır. Bu açıklamalara göre beş vakit namazın İsrâ' hâdisesinden önce yani yaklaşık olarak bi'set'in dördüncü yılında farz kılındığı ortaya çıkmaktadır. ${ }^{47}$

44 Mâverdî, en-Nüket ve'l-'uŷ̂n, 5/356.

45 Mâverdî, en-Nüket ve'l-'uŷ̂n, 5/357.

46 Ebü'l-Kâsım Mahmûd b. 'Ömer b. Muhammed ez-Zemahşerî, el-Keşşâf (Beyrut: Dâru'lKütübi'l-'Illmiyye, 1995), 4/383. Râzî de bu ifadelerin Zemahşerî gibi hem tesbîh hem de namaz manasına gelmesinin mümkün olduğunu söylemektedir. Bk. Râzî, Mefâtîhu'l-gayb, 28/152-153.

47 Derveze, et-Tefsîru'l-hadîs, 2/250. Ayrica bk. Ebû İshâk Ahmed b. Muhammed b. İbrâhîm en-Nîsâbûrî es-Sa'lebî, el-Keşf ve'l-beyân, thk. Ebû Muhammed b. 'Âşûr (Beyrut: Dâru İhyâi't-Türâsi'l-'Arabî, 2002), 9/106; Ebü'l-Hasen 'Alî b. Ahmed b. Muhammed b. 'Ali en-Nîsâbûrî Vâhidî, el-Vecîz, thk. Safvân 'Adnân Dâvûdî (Beyrut: Dâru'l-Kalem - ed-Dâru'ş-Şâmiyye, 1415), 1025; Ebû Muhammed Muhyissunne elHüseyn b. Mes'ûd b. Muhammed el-Ferrâ el-Begavî, Me'âlimu't-tenzîl, thk. 
M. ALTUNTAŞ / In the Light of Tafsīr Literature, Prayer (Salāt) in the Sūrahs Sent Down before the

Event of Isrā' | 73

Elmalılı (1878-1942) "secdelerin ardından" ifadesini, "tesbîh, her namazın arkasından yapılır" 48 şeklinde izâh ederek zımnen de olsa bu ifadelerin beş vakit namaza işaret ettiğini söylerken Mevdûdî doğrudan bu ifadeleri beş vakit namaz olarak tefsir etmiştir. ${ }^{49}$ Diğer taraftan günümüz müfessirlerinden Sait Şimşek de bu ifadeleri, namazın sabretmeye kaynaklık etmesinden dolayı beş vakit namaz olarak

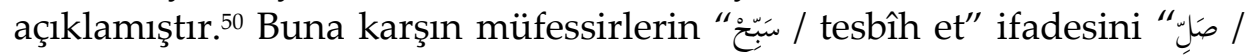
namaz kıl" şeklinde tefsir etmelerini isâbetli bulmayan Süleyman Ateş şöyle demektedir:

“Kanaatimize göre burada tesbîh ile kasit namaz değil, daha geniş anlamiyla Allah'1 anmak, O’nun şanının yüceliğini söylemek, duâ ve zikir ile O'na yönelmektir. Eğer tesbîhten maksat namaz olsaydı, secde arkalarından Allah'ın tesbîh edilmesi emredilmezdi. Çünkü secde namazın rüknüdür. Secde arkalarından "namaz kılın” sözü, uygun olmaz. Ama "secde arkalarından tesbîh edin" sözü çok yerindedir... Bu hadisler de tesbîh'in namazdan ayrı, bir zikir ve Allah'ın şânını yüceltme, bir duâ olduğunu ortaya koymaktadır. Demek ki âyetteki tesbîhi namaz diye tefsir etmek yanlıştır". ${ }^{51}$

Ancak yine Ateş bu âyetlerin tefsiri bağlamında önceki söylediklerinin aksine bir sonraki sayfada şöyle demektedir: “Bu âyetler Müslümanların, çok erken zamanlarda, günün belli başlı saatlerinde namaz kıldıklarını, duâ ve tesbîh ettiklerini gösterir. Fakat beş namaz

'Abdurrezzâk el-Mehdî (Beyrut: Dâru İhyâi't-Türâsi'l-'Arabî, 1420), 4/277-278; Ebû Muhammed 'Abdülhak b. Gâlib b. 'Abdirrahmân İbn 'Atiyye, el-Muharreru'l-vecîz, thk. 'Abdusselâm 'Abduşşâfî Muhammed (Beyrut: Dâru'l-Kütübi'l-'İlmiyye, 1422), 5/168; Ebü'l-Ferec Cemâluddîn 'Abdurrahmân b. 'Alî b. Muhammed İbnü'l-Cevzî, Zâdü'lmesîr, thk. 'Abdurrezzâk el-Mehdî (Beyrut: Dâru'l-Kitâbi'l-'Arabî, 1422), 4/165-166; Muhammed Tâhir İbn 'Âşûr, Tefsîru't-tahrîr ve't-tenvîr (Tunus: Dâru Sahnûn li'n-Neşr ve't-Tevzi', ts.), 26/327.

48 Elmalılı Muhammed Hamdi Yazır, Hak Dini Kur'ân Dili (İstanbul: Yenda Yayınları, 2001), $7 / 223$.

49 Mevdûdî, Tefhîmu'l-Kur'ân, 5/488-489.

50 M. Sait Şimşek, Hayat Kaynağı Kur'ân Tefsiri (İstanbul: Beyan Yayınları, 2012), 5/49.

51 Ateş, Yüce Kur'ân'ın Çă̆daş Tefsiri, 9/35. Kuşeyrî de bu âyetlerdeki “tesbîh et” ifadesini normal tesbîh olarak açıklamıştır. Kuşeyrî, Letâifü'l-işârât, 3/457. Benzer açıklamalar için bk. Muhsin Demirci, Kur'ân Tefsirinde Farklı Yorumlar (İstanbul: İfav Yayınları, 2017), 3/188-189. 
vaktini kesin çizgilerle belirleyen bir âyet yoktur. Bu husus, $\mathrm{Hz}$. Peygamber' in sünneti ve uygulamalarıyla belirlenmiştir". ${ }^{2}$

Her ne kadar âlimler, Kâf 39-40. âyetlerde geçen "güneşin doğuşundan ve batışından önce", "gecenin bir kısmında" ve "secdelerin ardından" ifadelerinin hangi vakitlere ve namazlara işaret ettiği konusunda farklı görüşler belirtseler de genel olarak bu ifadelerin beş vakit namazı belirttiğini söylemişlerdir. Ancak müfessirlerin bu

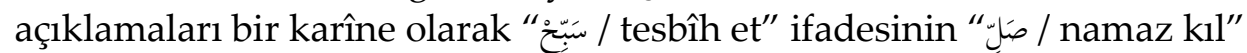
şeklinde tefsir edilmesine dayanmakta ve bu durum beş vakit namazın İsrâ gecesinde farz kılındı ğı hadisiyle çelişmektedir.

\section{3. 'Arâf Sûresi 31. Âyet}

Mekkî sûrelerde namaz kılındığından bahseden âyetlerden birisi de 'Arâf 31. âyetidir. "Ey Âdemoğulları, her mescide gidişinizde elbisenizi giyin." Derveze bu âyetler hakkında şöyle demektedir: 'Arâf 31-33. âyetler, Allah'ın divanında namaza duran mü'minlerin ihtişamlı olmasının gerekliliğini ortaya koymaktadır. Dolayısıyla Allah'ın huzurunda namaz kılarken ihtişamlı olmak mubahtır. ${ }^{53}$ İbn Kuteybe (öl. 276/889), Taberî, İbn Ebî Hâtim bu âyetin çıplak bir şekilde Kâ'be'de namaz kılan müşriklere yönelik olduğunu söylemektedir. ${ }^{54}$ Dolayısıyla bu âyet, "herhangi bir vakit belirlemesi olmaksızın" insanların namaz kılmak için Kâ'be'ye/mescide giderken zînetlerini/elbiselerini giymelerinden bahsetmektedir. "Zînet" kelimesini "giyilmesi âdetten olan güzel elbise" olarak açıklayan Abduh (1849-1905) buradaki emrin mutlak olduğunu ve her mescitte ibâdet için gidildiğinde ziynetin vâcipliğine işaret ettiğini söylemektedir. ${ }^{55}$ Diğer taraftan 'Arâf 170. âyette Yahudilerden bahisle "Onlar ki Kitâb'a sımsıkı sarılır ve namazı kılarlar" ifadesi geçmektedir. Mukâtil ve Derveze 'Arâf 163-172. âyetlerinin Medine'de nâzil olduğunu söylerken;"56 buna mukâbil Semerkandî (öl.

52 Ateş, Yüce Kur'ân'ın Çă̆daş Tefsiri, 9/37.

53 Derveze, et-Tefsîru'l-hadîs, 2/384.

54 Bk. İbn Kuteybe, Garîbü'l-Kur'ân, 144-145; Ahmed b. 'Alî Ebû Bekr er-Râzî el-Cessâs, Ahkâmü'l-Kur'ân, thk. Muhammed Sâdık el-Kamhâvî (Beyrut: Dâru İhyâi't-Türâsi'l'Arabî, 1405), 4/205-206.

55 Muhammed 'Abduh - Muhammed Reşid Rı̂a, Tefsîru'l-menâr (b.y.: el-Heyetü'1Misriyyetü'1-'Âmme li'1-Kitâb, 1990), 8/339.

56 Mukâtil b. Süleymân, Tefsîru Mukâtil b. Süleymân, 1/383; Derveze, et-Tefsîru'l-hadîs, $2 / 520$. 
M. ALTUNTAŞ / In the Light of Tafsīr Literature, Prayer (Salāt) in the Sūrahs Sent Down before the Event of Isrā' | 75

373/983) ve Sa'lebî (öl. 427/1035) gibi bazı müfessirler de bu sûrenin tamamının Mekkî olduğunu belirtmektedirler. ${ }^{57}$ Bu âyetlerin Mekkî olduğu dikkate alındığında Hz. Peygamber ve önceki dönemlerdeki Ehli kitâb'ın bir kısmının namaz kıldığı anlaşılmaktadır. Ancak bu namazın kaç vakit olduğu konusunda ilgili âyet bağlamında herhangi bir bilgi bulunmamaktadir.

\section{Cin Sûresi 18. Âyet}

Cin sûresinin 18. âyetinde namaz bağlamında şöyle denilmektedir: "Mescidler, Allah'a mahsustur. Allah'la beraber hiç kimseye yalvarmayın." Derveze'ye göre bu âyette Allah'a secde/ibâdet edilirken Oمَnسحِدَ" / mesâcid" kelimesini kilise, havra ve mescid olarak açıklayan Mukâtil ise şöyle demektedir: "Yahudiler ile Hıristiyanlar kilise ve havralarında namaz kılarken şirk koştukları için Allah, mü'minlere Kendisini tevhîd etmelerini/birlemelerini emretmektedir." ${ }^{59}$ İbn Kuteybe de Mukâtil'den farklı olarak "mesâcid" kelimesini "السّجود / sucûd" olarak tefsir etmiştir. ${ }^{60}$ İbn Ebî Hâtim (öl. 327/938), İbn 'Abbâs'tan nakille bu âyet indiğinde sadece Mescid-i Harâm ve Mescid-i İlyâ/Beytü'l-Makdis' in var olduğunu söylemektedir. ${ }^{61}$ Buna göre âyet bir taraftan Ehl-i kitâb'a diğer taraftan da Müslümanlara, ibâdet mekânlarında samimi olmalarını ve sadece O'nun için namaz kılmalarını emretmektedir. Cin sûresinde 18. âyetteki "mescid" kelimesi dışında namaz vakitlerine işaret eden herhangi bir ifade bulunmamaktadır.

\section{Furkân Sûresi 60 ve 64 . Âyetler}

Furkân 60. âyette müşriklere hitâben büyüklenmeden "Rahmân'a secde edin" emri yer alırken 64. âyette Müslümanların özelliklerinden biri

57 Semerkandî, Bahru'l-‘ulûm, 1/502; Sa'lebî, el-Keşf ve'l-beyân, 4/214.

58 Derveze, et-Tefsîru'l-hadîs, 3/16.

59 Mukâtil b. Süleymân, Tefsîru Mukâtil b. Süleymân, 3/407. Benzer açıklamalar için bk. Ebû Muhammed Sehl b. 'Abdillâh b. Yûnus b. Refî' et-Tüsterî, Tefsîru't-Tüsterî, thk. Muhammed Bâsil ‘Uyûnu's-Sûd (Beyrut: Dâru'l-Kütübi'l-'İlmiyye, 1423), 179.

60 Kuteybe, Garîbü'l-Kur'ân, 420.

61 İbn Ebî Hâtim, Tefsîru'l-Kur'âni'l-'azîm, 10/3379. Ömer Faruk Harman, "Mescid-i İlyâ" hakkında şöyle demektedir: "Erken dönem kaynaklarında âyetteki "el-Mescidü'lAksa" kavramı yer almayıp, "Mescidü İlyâ" kavramı kullanılmıştır." Bk. Ömer Faruk Harman, "İslâmiyet ve Kudüs", Milel ve Nihal 16/1 (2019), 23. 


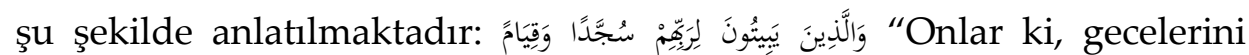
Rablerine secde ederek ve kıyâma durarak geçirirler".62 Mukâtil, "Rahmân'a secde edin" emrini "Rahmân için namaz kılın" ve 64. âyeti de herhangi bir vakit belirtmeksizin Müslümanların geceleri "namaz k1larak"63 ihyâ ettikleri şeklinde yorumlamıştır. Taberî " “يَّ" ifadesini vakit belirtmeksizin "Allah için namaz kılarlar" 64 şeklinde tefsir ederken Semerkandî, İbn 'Abbâs'tan nakille buradaki namazın yatsıdan sonra kılınan iki rekât veya daha fazla namazları; Kelbî'den rivâyetle de akşam ve yatsıdan sonra kılınan iki ve dört rekâtlık nafile namazları belirttiğini söylemişlerdir. ${ }^{65}$ Zemahşerî ise bu âyetteki "secde" ve "kıyâm" kelimelerinin akşam ve yatsıdan sonra kılınan ikişer rekâtlık namaz olduğunu söylemiş ve Müslümanların gecenin tamamını veya en azından çoğunu ibadetle geçirdiklerini belirtmiştir. ${ }^{66}$

\section{Fâtır Sûresi 18 ve 29. Âyetler}

Fâtır sûresi 18. âyette الصَّة "Sen ancak görmedikleri halde Rablerinden korkan ve namaz kılanları uyarabilirsin"

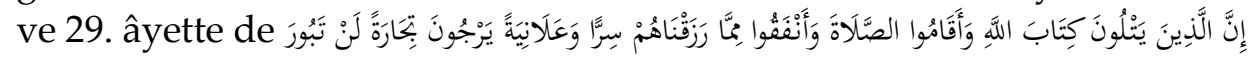
“Allah'ın Kitâb'ını okuyanlar, namazı kılanlar ve kendilerine verdiğimiz rızıktan hayır için gizli ve açık harcayanlar, asla batmayacak bir ticaret

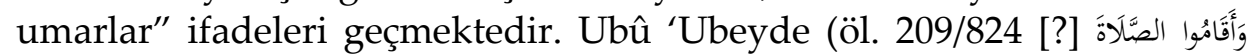
ifadesini "Vakit ve hududlarına/sınırlarına riâyet ederek namaza devam ederler"67 şeklinde açıklarken Taberî bu ifadeyi " الصلاة المفروضة / farz namazlar" الصَّلَأَ ifadesi, Medenî sûrelerde olduğu gibi genel olup, pek çok müfessir tarafından beş vakit namaz olarak açıklanmıştır. ${ }^{69}$ Hatta Kurtubî bu

62 el-Furkân 25/60.

63 Mukâtil b. Süleymân, Tefsîru Mukâtil b. Süleymân, 2/441.

64 Taberî, Câmiu'l-beyân, 11/6520.

65 Semerkandî, Bahru'l-'ulûm, 2/544.

66 Zemahşerî, el-Keşşâf, 3/284.

67 Ebû 'Ubeyde Ma'mer b. el-Müsennâ et-Teymî el-Basrî, Mecâzu'l-Kur'ân, thk. Muhammed Fuâd Sezgin (Kâhire: Mektebetü'1-Hancî, 1381), 2/155.

68 Taberî, Câmiu'l-beyân, 12/7161.

69 Bk. Mukâtil b. Süleymân, Tefsîru Mukâtil b. Süleymân, 3/75-76; İbn Ebî Zemenîn, Tefsîru'l-Kur'âni'l-'azîz, 4/28-30; Kuşeyrî, Letâifü'l-işârât, 3/200; Zemahşerî, el-Keşşâf, 3/594; İbn 'Atiyye, el-Muharreru'l-vecîz, 4/435, 438. 
M. ALTUNTAŞ / In the Light of Tafsīr Literature, Prayer (Salāt) in the Sūrahs Sent Down before the Event of Isrā' | 77

ifadenin beş vakit namaza ilaveten diğer bütün nâfile namazları da kapsadığını belirtmektedir. ${ }^{70}$

Derveze ise Fâtır 18 ve 29. âyetler hakkında şöyle demektedir:

“Peygamber'in üzerine düşen görev sadece Rablerine iman edenlere, O'nu görmeseler de O'ndan korkanlara ve namazı dosdoğru kılıp, iyilik ve hidâyeti isteyenlere önem vermesidir... Allah'ın kitâbını okuyanlar, namazı dosdoğru kılanlar ve hayır için harcamada bulunanlar birbirine bağlanmaktadır". ${ }^{71}$

Buna mukâbil Fâtır 18. âyeti müşriklerden namaz kılanlarla irtibatlandıran Süleyman Ateş pek çok müfessirin aksine şöyle demektedir: "Bu âyet de Arap toplumunda eskiden beri namaz ibâdetinin bulunduğunu kanıtlayan âyetlerden biridir. Demek ki toplum içinde gerçekten Allah'tan korkan ve vakitli, düzenli olmasa da namaz kılanlar vardı ki Yüce Allah, ancak öylelerinin uyarılarını dinleyeceğini bildiriyor".72 Kanaatimizce bu yorum âyetin bağlamina uygun düşmemektedir. Zira Beydâvî (öl. 685/1286) bu âyette kastedilen kişilerin müşrikler değil; Müslümanlar olduğunu belirtmektedir. ${ }^{73}$

\section{Meryem Sûresi 31, 55 ve 59. Âyetler}

Meryem 51. âyette Hz. Îsâ namaz konusunda şöyle demektedir:

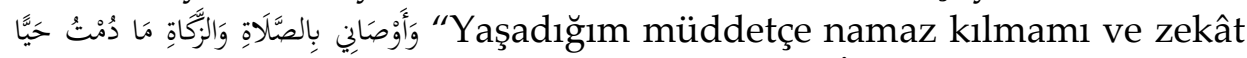
vermemi emretti." Meryem 55. âyette Hz. İsmâil hakkında şöyle

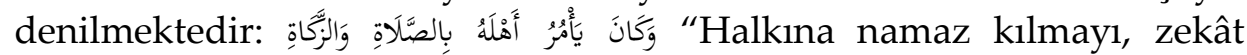

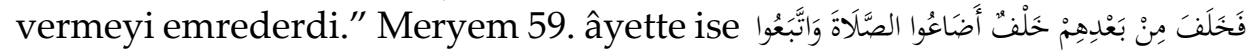
"Onların ardından namazı bırakan ve şehvetlerinin peşine düşen bir nesil geldi." Bu âyet hakkında Derveze şöyle demektedir: "Âyetlerde namazı bırakarak şehvetlerine tâbi olanlar arasındaki bağlantıya dikkat çekiliyor. Bu ise şehvetlere tâbi olmanın, ibâdeti ve zikri bırakmanın bir sonucu olduğunu gösteriyor." ${ }^{74}$ Meryem 31, 55 ve 59. âyetler, insanlıkla yaşıt olan namaz ibâdetinin her ümmete farz kılındığını ve ancak onların

70 Kurtubî, el-Câmiu' li ahkâmi'l-Kur'ân, 14/308.

71 Derveze, et-Tefsîru'l-hadîs, 3/116-117.

72 Ateş, Yüce Kur'ân'ın Çă̆daş Tefsiri, 7/300.

73 Nâsıruddîn Ebû Sa'îd 'Abdullâh b. Ömer b. Muhammed eş-Şîrâzî el-Beydâvî, Envâru't-tenzîl, thk. Muhammed Abdurrahman el-Maraşlı (Beyrut: Dâru İhyâi'tTürâsi'l-'Arabî, 1418), 4/257.

74 Derveze, et-Tefsîru'l-hadîs, 3/167. 
78 | M. ALTUNTAŞ / Tefsir Literatürü Işı̆̆ında İsrâ Olayından Önce Nâzil Olan Sûrelerde Namaz

bu ibâdeti zamanla terk ettiklerini ve hak yoldan ayrıldıklarını ortaya koymaktadır. Meryem sûresinin namazla ilgili âyetlerinde vakitle ilgili herhangi bir işaret bulunmamaktadır.

\section{Tâhâ Sûresi 14, 130 ve 132. Âyetler}

Tâhâ sûresi Hz. Ömer'in Müslüman olmasından önce ve Meryem sûresinden sonra Hz. Osmân'ın Mushaf tertibine göre 45. sırada nâzil olmuştur. Hz. Ömer'in risâletin beşinci yılında Müslüman olduğu dikkate alındığında bu sûrenin bu tarihten önce indiği anlaşılmaktadır. ${ }^{75}$ Tâhâ sûresinin 14. âyetinde vakit belirtilmeksizin namaz hakkında Hz.

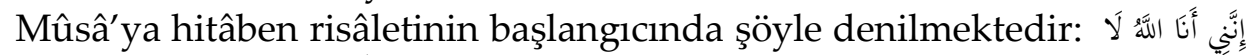
Wüphesiz ben, Allah'1m. Benden başka ilah yok. Bana kulluk et, beni anmak için namaz k1l." Ardından Tâhâ $130 .{ }^{76}$ âyette ise Kâf 39-40. âyetlerde olduğu gibi namaz vakitleri hakkında şöyle

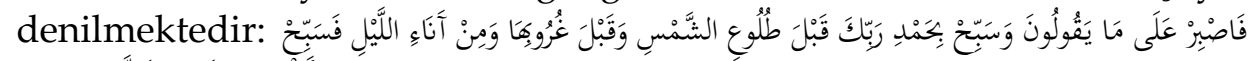
وأَطْرافَ النَّهَارِ لَعَلَّكَ تَرْضَى batmadan önce Rabbini hamd ile tesbîh et. Gecenin bazı saatlerinde ve gündüzün etrafında da tesbîh et ki 'Allah'ın' hoşnutluğuna erişesin." Ardından Tâhâ 132. âyette Hz. Peygamber'e, ehline namazı emretmesi

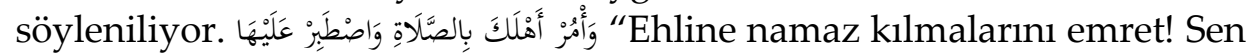
de namaza devam et!" Tâhâ 14. âyet namazın önceki milletlere de farz kılındığını, 130. âyet ise beş vakit namazın vakitlerini ve 132. âyet ise namazın farziyetini belirtmektedir.

Mukâtil, Tâhâ 130. âyet bağlamında namaz hakkında şöyle demektedir:

“Namaz önceleri sabah ve akşam olmak üzere ikişer rekâttı. Nebî, Mi'rac'a yükseldiğinde akşam namazı hariç beş vakit namaz ikişer rekât olarak farz kılındı. Medine'ye hicret edince (sabah ve akşam namazı dışındaki) namazları (dörte) tamamlamakla emrolundu.

Namazların (iki, üç ve dört rekât) olmak üzere üç hali vardır". 77

Mukâtil'in bu yorumu bu sûreden önce nâzil olan Kâf sûresinin ilgili âyetleri bağlamında yaptığı beş vakit namaz açıklamalarıyla çelişmektedir. Onun bu çelişkisi muhtemelen âyetleri nüzûl tertibine göre

75 Ateş, Yüce Kur'ân'ın Çă̆daş Tefsiri, 5/421.

76 Derveze, Tâhâ 130-131. âyetlerin Medîne'de nâzil olduğu konusundaki rivâyetlerin konu bütünlüğü açısından doğru olmadığını söylemektedir. Bk. Derveze, et-Tefsîru'lhadîs, 3/186.

77 Mukâtil b. Süleymân, Tefsîru Mukâtil b. Süleymân, 2/345. 
M. ALTUNTAŞ / In the Light of Tafsīr Literature, Prayer (Salāt) in the Sūrahs Sent Down before the

Event of Isrā' | 79

tefsir etmemiş olmasından kaynaklanmaktadır. Süfyân es-Sevrî (öl. 161/778) Tâhâ 130. âyetteki vakit ifadelerini toplu olarak "salâtu mektûbe/beş vakit namaz"78 olarak açıklamıştır. Tâhâ 130. âyetteki "سَبّْن" kelimesini "صَّل / namaz k11" şeklinde açıklayan Mukâtil, Kâf 39-40. âyetlerde izah ettiği gibi "güneş doğmadan önce” ifadesini sabah; "güneş batmadan önce" ifadesini öğle ve ikindi; "gece saatlerinde" ifadesini akşam ve yatsı ${ }^{79}$ namazı olarak açıklamıştır. Birtakım farklılıklarla beraber müfessirlerin geneli bu ifadeleri beş vakit namazı kapsayacak şekilde açıklarken;80 Kuşeyrî (öl. 465/1072) bu âyetteki “" iَّبَّْ ifadesini normal tesbîh olarak izah etmiştir. ${ }^{81}$ Benzer şekilde Râzî de "سَبَّح" " ifadesinin "namaz kıl" şeklinde anlaşılmasına ilaveten Ebû Müslim'den rivâyetle "tenzîh" ve "iclâl" manasına hamledilmesinin de mümkün olduğunu belirtmektedir. Buna göre âyetin anlamı "Bu vakitlerde Allah'1 tenzîh ile meşgul ol" demektir. ${ }^{82}$

Derveze de müfessirlerin genelinin yaptığı açıklamalara paralel olarak bu âyetler hakkında şöyle demektedir:

“Bazı müfessirler, 130. âyette Hz. Peygamber'e emredilen tesbîh vakitlerinin beş vakit namazın vakitleri olduğundan hareketle beş vakit namazı kılmanın tesbîh etme anlamına geldiğini söylemişlerdir... Âyetin üslubu, siyakla olan ahenkliği ve 'yekûlûne' zamirinin önceki âyetlerdeki kâfirlere râci olması Mekkî’liğini ve Medenî oluşuyla ilgili rivâyetlerin ise kuşkulu olduğunu göstermektedir" ${ }^{83}$.

“İkinci âyette (Tâhâ 132) aynı şekilde Hz. Peygamber'in ve ailesinin namaza devam etmesi isteniliyor... Bunun için âyetin Medenî olduğuyla ilgili rivâyetin kuşkulu olduğunu düşünüyor ve Mekkî olduğu görüşünü tercih ediyoruz. Çünkü âyetin Mekke dönemindeki Hz. Peygamber'in sîretinin şartlarıyla ilişkisi vardır. Ayrıca Tâhâ 131-132.

78 Ebû 'Abdillâh Süfyân b. Saî’d b. Mesrûk es-Sevrî el-Kûfî, Tefsîru Süfyân es-Sevrî (Beyrut - Lübnân: Dâru'l-Kütübi'l-'İlmiyye, 1983), 198.

79 Mukâtil b. Süleymân, Tefsîru Mukâtil b. Süleymân, 2/345.

80 Ferrâ, Me'âni'l-Kur'ân, 2/195; Taberî, Câmiu'l-beyân, 9/5982-5984; Semerkandî, Bahru'l'ulûm, 2/417; İbn Ebî Zemenîn, Tefsîru'l-Kur'âni'l-'azîz, 3/137; Zemahşerî, el-Keşşâf, 3/9394.

81 Kuşeyrî, Letâifü'l-işârât, 2/487-488.

82 Râzî, Mefâtîhu'l-gayb, 22/113.

83 Derveze, et-Tefsîru'l-hadîs, 3/217. 
80 | M. ALTUNTAŞ / Tefsir Literatürü Işı̆̆ı̆nda İsrâ Olayından Önce Nâzil Olan Sûrelerde Namaz âyetlerin 130. âyette Hz. Peygamber'e yöneltilen hitâbı tamamlayıcı nitelikte olduğu görülmektedir". 84

Tâhâ sûresinin 130. âyeti hakkında Süleyman Ateş de hem Derveze ve hem de ondan önceki bazı müfessirlerin görüşlerine benzer bir açıklama yaparak şöyle demektedir:

“Bazı müfessirlere göre 130. âyette namaz vakitleri belirlenmektedir: Bunlardan kimilerine göre güneş doğmazdan önce sabah namazı, batmazdan önce öğle ile ikindi namazları, ânâelleyl (gece saatleri) ise akşam ve yatsı namazlarıdır. Etrâfennehâr (gündüzün uçları) ise sabah ve akşam namazlarını pekiştirir. Kimine göre güneş doğmazdan önce sabah namazını, batmazdan önce ikindi namazını, ânâelleyl akşam ve yatsı namazlarını gösterir. Öğle namazı hariç kalır. Demek ki bu âyet beşten az namazı göstermektedir" ${ }^{85}$

Süleyman Ateş'in "Demek ki bu âyet beşten az namazı göstermektedir" ifadesi pek isabetli değildir. Zira yukarıda da işaret edildiği üzere başta Mukâtil ve Süfyân es-Sevrî olmak üzere ilk dönemlerden itibaren bu ifadeler müfessirlerin geneli tarafından beş vakit namazı kapsayacak şekilde tefsir edilmiştir. Bu âyetler bağlamında değinmemiz gereken hususlardan biri de Muhammed Hamidullah'in (1908-2002) bu konudaki görüşleridir. Hamidullah İslam Peygamber'i adlı eserinin "Mi'rac'ın Teferruatı" adlı başlığı altında önce şu bilgileri vermektedir:

“Cenâbı Hak, Semâvî Arş'ında bulunan ilâhî Hazineler'den elimizde bulunan Kur'ân'ın ikinci sûresinin (Bakara) en sonuncu iki âyetini çekip çıarır ve bu yolculuğun bir hâtırası olmak üzere Muhammed A.S.'a hediye olarak verir; en sonunda da 'günlük beş vakit namazını' Müslümanlara farz kılar (esasında 50 vakit farz kılınmıştı, fakat dönüş yolu üzerinde tekrar karşılaştı̆̆ı Mûsâ A.S.'ın öğütlemesi üzerine tekrar geri dönüp İlâhî Eşiğe (Kürsî) tekrar vardı ve bu sayının azaltılması için yakardı. Neticede bu, her biri on yerine geçmek üzere beş vakit namazı şeklinde bir azaltılmaya tâbî tutulmuştur)" ${ }^{86}$

84 Derveze, et-Tefsîru'l-hadîs, 3/218.

85 Ateş, Yüce Kur'ân'ın Çağdaş Tefsiri, 5/457.

86 Muhammed Hamidullah, İslâm Peygamberi, çev. Salih Tuğ (İstanbul: İrfan Yayımcılık, 1995), 1/138-139. Hamidullah namazların Mi'rac'da farz kılındığına dâir başka bir yerde şöyle demektedir: "Bilindiği gibi günün beş vaktinde namaz kılmak Müslümanlara, Resûlullâh'ın göğe yükselişi ('urûc, Mi'rac) esnasında farz olarak emredildi." Bk. Hamidullah, İslâm Peygamberi, 2/731. 
M. ALTUNTAŞ / In the Light of Tafsīr Literature, Prayer (Salāt) in the Sūrahs Sent Down before the

Event of Isrā' | 81

Beş vakit namazın Mi'rac'da farz kılındığ ${ }^{87}$ kabulünden hareketle bu cümleleri söyleyen Hamidullah ilgili eserinin ikinci cildinin "Namazlar" başlı̆̆ı altında ise Mekke'de fakat İsrâ sûresinden önce nâzil olan ve namazların vakitlerine işaret eden Tâhâ 130. âyete atfen şu cümleleri söylemektedir:

“Kur'ân-1 Kerîm, günde beş vakit namazını bütün insanlar için ana akîde (farz) olarak göstermiştir. “... (1) Güneşin doğuşundan ve (2) batışından önce, (3) gece saatlerinde, Rabbinin her şeyden arınmış ve ulu varlığını O'na hamd ve teşekkür ederek yücelt... ve kezâ (4-5) günün her iki başında onu yücelt..." (Tâhâ 20/130). Âyette 'her iki tarafında' (etrâf) terimi çoğul halde bulunduğu için (diğer bir âyette (Hûd 11/114) de tarafey yani iki baş, iki taraf şeklinde te' yid edildiğine göre) bu çoğul ifadesini en az (iki baş) şeklinde anlamamız gerekecektir. Âyette (1) numara altında esasen güneşin doğuşundan önce kılınacak namaza işaret edildiğine göre 'güneşin her iki başı' (etrâf) terimindeki iki gündüz namazından biri 'öğlen', diğeri güneş battığında kılınan 'akşam' namazı olmaktadır. Bu âyette işaret edilen zamanlamaya göre, sabahleyin erkenden kalkıldığı zaman sabah namazı (salâtu'l-fecr), güneş tepe noktasına çıktıktan hemen sonra öğlen (salâtu'z-zuhr) ve öğleden sonraki zamanın son bulmasına doğru ikindi (salâtu'l-'asr), güneş battıktan hemen sonra akşam (salâtu'l-mağrib) ve gece yatmadan evvel yatsı (salâtu'l-'işâ) namazının kılınması lâzım gelecektir". ${ }^{88}$

Bu iki alıntıda açıça görüldüğü üzere Muhammed Hamidullah'ın açıklamalarında nuzûl tertibi bakımından çelişkiler bulunmaktadır. Zira $\mathrm{o}$, birinci alıntı da beş vakit namazın İsrâ ve Mi'rac olayında farz kılındığını söylemektedir. İkinci alıntıda ise beş vakit namaza İsrâ ve Mi'rac'dan önce nâzil olan Tâhâ sûresinin 130. âyetini delil olarak sunmaktadır. ${ }^{89}$ Esasında bu durum pek çok müfessir tarafından bu şekilde açıklanmıştır. Kanaatimizce bu hata veya çelişki âyetlerin nuzûl tertibine göre tefsir edilmemesinden kaynaklanmaktadır.

\section{9. Şu'arâ Sûresi 218-219. Âyetler}

Şu'arâ 218 ve 219. âyetlerde namaz hakkında şöyle denilmektedir:

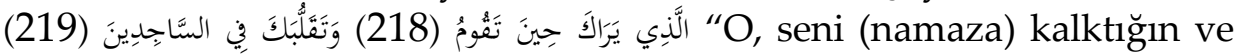
secde edenler ile (secdeye) yatıp kalktığın zaman görür." Bu âyetlerde Hz.

87 Hamidullah, İslâm Peygamberi, 1/138.

88 Hamidullah, İslâm Peygamberi, 2/728-729.

89 Hadiye Ünsal'ın derlediği bütün nüzûl tertiplerine göre Tâhâ sûresi İsrâ'dan önce nâzil olmuştur. Bk. Öztürk - Ünsal, Kur'ân Tarihi, 258-318. 
82 | M. ALTUNTAŞ / Tefsir Literatürü Işı̆̆ında İsrâ Olayından Önce Nâzil Olan Sûrelerde Namaz

Peygamber ve mü'minlerin secdelerinden/namazlarından bahsedilmektedir. Bu bağlamda pek çok müfessir iَ fiilini; namaza kalkma ve السَّاِِدِينَ kelimesini de "namaz k1lan mü'minler" olarak açıklamıştır. ${ }^{90}$ Bazı müfessirler 219. âyetteki "tekallüb" kelimesini Hz. Peygamber'in annesinden doğuncaya kadar Hz. Âdem'den itibaren mü'min kadınların rahimlerinde, peygamberlerin sulblerinde devam ettiği şeklinde açıklamışlardır. ${ }^{91}$ Fakat âyetteki mana gayet açık olup bu da Allah'ın onu yalnız ve mü'minlerle beraber namaz kılarken gördüğü şeklindedir.92 Şu'arâ 218-219. âyetlerde namaz vakitlerinden söz edilmemiştir.

\section{Neml Sûresi 3, 24-25. Âyetler}

Neml sûresinin üçüncü âyetinde Medenî sûrelerde olduğu gibi

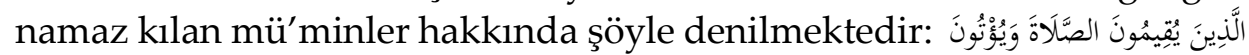
"Onlar, namazı kılarlar, zekâtı verirler ve âhirete de

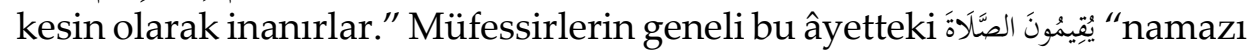

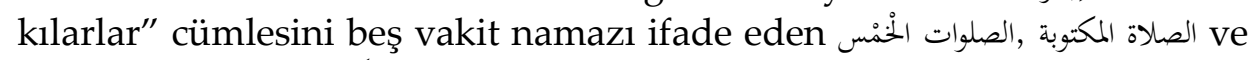

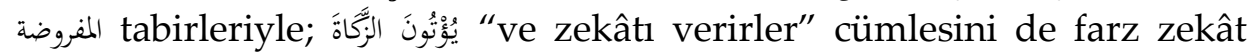
olarak izah etmişlerdir.93 Ancak İbn 'Atiyye sûrenin Mekkî olması hasebiyle buradaki zekâtın "tahâret/temizlenme" anlamında olmasının mümkün olduğunu söylemektedir. ${ }^{94}$

Derveze bu âyet hakkında şöyle demektedir: "Üçüncü âyette mü'minlerin; namaz kılmakla, zekât vermekle, âhirete inanmakla vasfedilmesi İslâm'ın îmân ve amelden ibâret olduğunu göstermektedir." 95 Süleyman Ateş ise "namazlarını kılarlar" tabiri hakkında vakit belirtmeksizin, Kâf 39-40. âyet hakkında yaptığ

90 Ebu'l-Haccâc Mücâhid b. Cebr el-Mahzûmî, Tefsîru Mücâhid, thk. Muhammed 'Abdüsselâm Ebu'n-Nîl (Misır: Dâru'l-Fikri'l-İslâmiyyi'l-Hadîse, 1989), 514; Mukâtil b. Süleymân, Tefsîru Mukâtil b. Süleymân, 2/466; Süfyân es-Sevrî, Tefsîru Süfyân es-Sevrî, 230; Taberî, Câmiu'l-beyân, 11/6612-6613.

91 Bk. Semerkandî, Bahru'l-'ulûm, 2/570; Sa'lebî, el-Keşf ve'l-beyân, 7/184.

92 Derveze, et-Tefsîru'l-hadîs, 3/268.

93 Mukâtil b. Süleymân, Tefsîru Mukâtil b. Süleymân, 2/469; Taberî, Câmiu'l-beyân, 11/66216622; Semerkandî, Bahru'l-'ulûm, 2/572; İbn Ebî Zemenîn, Tefsîru'l-Kur'âni'l-'azîz, 3/293; Begavî, Me'âlimu't-tenzîl, 3/489; Zemahşerî, el-Keş̧âf, 3/336; Râzî, Mefâtîhu'l-gayb, 24/540; Kurtubî, el-Câmi' li ahkâmi'l-Kur'ân, 1/159-173; 13/145.

94 İbn 'Atiyye, el-Muharreru'l-vecîz, 4/248.

95 Derveze, et-Tefsîru'l-hadîs, 3/283. 
M. ALTUNTAŞ / In the Light of Tafsīr Literature, Prayer (Salāt) in the Sūrahs Sent Down before the

Event of Isrā' | 83

açıklamalarla çelişir bir şekilde şöyle demektedir: "Mekke devrinin ortalarında inmiş olan bu sûrede mü'minler, namazlarını kılan, zekâtlarını veren... olarak nitelendirildiklerine göre bundan mü'minlerin, Mekke devrinin tâ ilk zamanlarında namazlarını kılıp zekâtlarını verdikleri anlaşılır" ${ }^{96}$ Neml 24-25 âyetlerde ise güneşe secde eden Sebe' halkının her şeyi bilen Yüce Allah'a secde etmeleri gerektiği anlatılmaktadır. Son olarak bize göre Kâf 39 ve Tâhâ 130. âyetlerde belirtilen beş vakit namazı tekrar eden İsrâ sûresinin 78. âyetiyle konumuzu tamamlamak istiyoruz.

\section{1. İsrâ Sûresi 78 ve 110. Âyetler}

İsrâ 78. âyette namaz ve namaz vakitleri hakkında şöyle

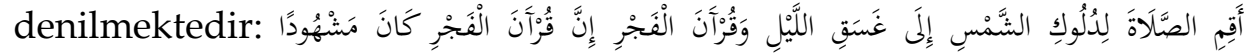
"Güneşin inişe geçmesinden gece karanlığının bastırmasına kadar ki namazları ve sabah namazını kıl. Çünkü sabah namazı şahitlidir." Bu âyette beş vakit namazın vakitlerinin anlatıldığını söyleyen Mukâtil, "dulûku'ş-şems'in" öğle ve ikindi, “ğaseki'l-leyl'in" akşam ve yatsı ve "Kur'âne'l-fecr'in" de sabah namazının vaktini anlattığını söylemektedir. ${ }^{97}$ Buna karşın Süleyman Ateş bu âyette üç vaktin anlatıldığını belirtmektedir. ${ }^{98}$ İsrâ 110. âyet ise namazdaki sesle ilgilidir.

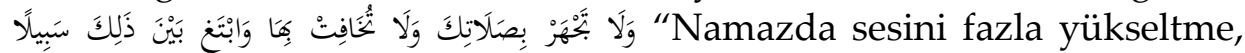
büsbütün de kısma; ikisi arasında bir yol tut." Mukâtil bu âyetin nüzûl sebebi hakkında şöyle demektedir:

“Hz. Peygamber, Mekke' de Safâ'nın yanında Ebû Süfyân'ın evine yakın bir yerde namaz kılıyordu. Bir gün sabah namazını kılarken yüksek sesle Kur'ân okuyunca Ebû Cehl: 'Niye Allah'a iftira ediyorsun?' dedi. Bunun üzerine Hz. Peygamber sesini iyice kıstı. Bu sefer ashâbı Kur'ân'ı duyamadı. Bunun üzerine Ebû Cehl: 'Ey Kureyşliler! Ebû Kebşe'nin oğluna yaptığımı gördünüz mü? Nihayet sesini kıstı' dedi". 99

96 Ateş, Yüce Kur'ân'ın Çă̆daş Tefsiri, 6/361-362.

97 Mukâtil b. Süleymân, Tefsîru Mukâtil b. Süleymân, 2/269. Ayrıca bk. Ferrâ, Me'âni'lKur'ân, 2/129; Taberî, Câmiu'l-beyân, 9/5554-5556; Semerkandî, Bahru'l-'ulûm, 2/324; Mâverdî, en-Nüket ve'l-'uyûn, 3/262-263; Zemahşerî, el-Keşşâf, 2/259; Derveze, etTefsîru'l-hadîs, 3/419; 5/40.

98 Ateş, Yüce Kur'ân'ın Çă̆daş Tefsiri, 5/240-241.

99 Mukâtil b. Süleymân, Tefsîru Mukâtil b. Süleymân, 2/277. 
Yine o, âyetin tefsirinde şöyle demektedir: "Müşriklerin duyup da sana eziyet edecekleri şekilde namazında kırâatini yükseltme. Ashâbının duyamayacağı kadar da Kur'ân'1 gizli okuma". ${ }^{100}$ Derveze de bu âyet hakkında şu açıklamaları yapmaktadır: Hz. Âişe'nin aktardığına göre bu âyet duâ hakkındadır. Müfessirler, İbn Abbâs'tan nakille bu âyetin gizli okumayı yasaklamak için indiğini söylemektedirler. Diğer taraftan Kur'ân'ın açıtan tilâvet edilmesini kâfirlerin dil uzatma sebebi olarak gösteren rivâyet, mantıklı değildir. Zira Hz. Peygamber risâlet vazifesinin bir gereği olarak her fırsatta kâfirlere Kur'ân okuyor, onlar da Kur'ân'ın sihir ve eskilerin masalları olduğunu söyleyerek Kur'ân'ı ve Hz. Peygamber'i yalanliyorlardi.

\section{Sonuç}

İbn Hişâm, İbn İshâk'tan namaz farz kılındığında Cibrîl'in (a.s) Hz. Peygamber'e abdest almayı ve beş vakit namaz kılmayı öğrettiğini rivâyet etmektedir. Mukâtil b. Süleymân da 11. sırada nâzil olan Duhâ sûresinin son âyeti bağlamında senetsiz olarak buna benzer bir rivâyet aktarmaktadır. Diğer taraftan yaygın kanaate göre beş vakit namazın farz kılındığı İsrâ olayı, hicretten yaklaşık bir buçuk yıl önce gerçekleşmiştir. Bütün bu rivâyetler dikkate alındığında beş vakit namazın ne zaman başladığını belirlemek zor görünmektedir.

Bu bağlamda Hz. Peygamber'in "Fâtiha'sız namaz olmaz" sözü dikkat çeken bir husustur. Bununla beraber İlk nâzil olan sûreler arasında yer alan 'Alak sûresinin ilk beş âyetinden bir yıl sonra indiği tahmin edilen 9-10. âyetlerinde Hz. Peygamber'in namaz kıldığı sırada Ebû Cehl'in onu bu ibâdetten engelleme girişimlerinin anlatılması namaz ibâdetinin risâletin ilk yıllarında başladığını göstermektedir. Hadis kaynaklarında risâletin ilk yıllarında sabah ve akşam olmak üzere iki vakit namazın kılındığına dâir rivâyetler de bunu teyit etmektedir. Bununla beraber mutlak anlamda "zaman'ın" yanında "ikindi namazı" olarak da tefsir edilen 'Asr kelimesi hariç Kâf sûresinden önceki sûrelerde namazın kaç vakit olduğuna dair net veri/bilgi bulunmamaktadır.

Nüzûl tertiplerinin tamamında Kâf ve Tâhâ sûreleri İsrâ'dan ve dolayısıyla Mi'rac olayından önce nâzil olmuştur. İsrâ sûresinden önce

100 Mukâtil b. Süleymân, Tefsîru Mukâtil b. Süleymân, 2/277. Ayrıca bk. Ebû 'Ubeyde, Mecâzu'l-Kur'ân, 1/392; Taberî, Câmiu'l-beyân, 9/5603-5609; Semerkandî, Bahru'l-'ulûm, 2/333; Zemahşerî, el-Keşşâf, 2/673. 
M. ALTUNTAŞ / In the Light of Tafsīr Literature, Prayer (Salāt) in the Sūrahs Sent Down before the

Event of Isrā' | 85

34. sırada nâzil olan Kâf 39 ve 45. sırada nâzil olan Tâhâ 130. âyetlerinde, Hz. Peygamber'e günün beş vaktinde Allah'1 "tesbîh" etmesi

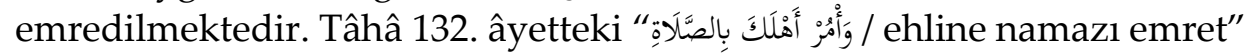
cümlesi, "tesbîh et" ifadesinin "namaz kıl" şeklinde tefsir edilmesini mümkün kılmaktadır. Tesbîh'in her zaman olabileceği hususu dikkate alındığında, bu âyetlerdeki "tesbîh et" ifadesinin namaz ibâdetine işaret ettiğini söylemek mümkün görünmektedir. Buradan hareketle bazı müfessirler bu âyetlerdeki "güneş doğmadan önce" ifadesini sabah, "güneş batmadan önce" ifadesini öğle ve ikindi ve "gece saatlerinde" ifadesini akşam ve yatsı namazlarının vakitleri olarak açıklamışlardır. Ayrıca Hz. Mûsâ ve Hz. İsâ'ya atfen Meryem 31 ve Tâhâ 14. âyetlerde risâletlerinin başlangıcında hemen namaz kılmakla memur kılınmaları da bu konuda bir karîne olarak değerlendirilebilir. Buna göre beş vakit namazın Kâf sûresinin 39. âyetiyle başladığını; Tâhâ 130 ve İsrâ 78. âyetleriyle tekrar edildiğini söylemek imkân dâhilinde gözükmektedir.

Sonuç olarak bazı müfessirler, Kâf 39-40 ve Tâhâ 130. âyetlerdeki “سَّ / tesbîh et" emrini "namaz k1l” anlamında tefsir ederek beş vakit namazın Mi'rac'dan önce başladığı sonucuna varmışlardır. Ancak bu durum namazın beş vakit olarak farz kılındığı meşhur Mi'rac hadisesi ile

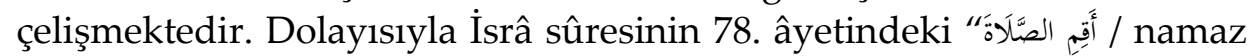
kıl" emri ve Mi'rac hadisesinde namazla ilgili anlatılan hususlar, Kâf 39

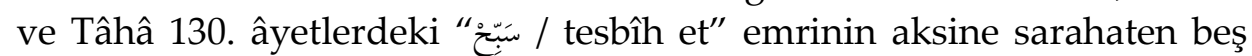
vakit namaza işaret etmektedir. Buna göre beş vakit namazın İsrâ ve Mi’rac olayıyla başladığını söylemek daha makul görünmektedir.

\section{Kaynakça}

'Abduh, Muhammed - Rızâ, Muhammed Reşid. Tefsîru'l-menâr. 12 Cilt. b.y.: el-Heyetü'l-Misriyyetü'1-'Âmme li'l-Kitâb, 1990.

Âlûsî, Şihâbüddîn Mahmûd b. 'Abdillâh el-Hüseynî. Rûhu'l-me'ânî. thk. 'Abdulbârî 'A tiyye. 15 Cilt. Beyrut: Dâru'l-Kütübi'l-'Illmiyye, 1415.

Ateş, Süleyman. Yüce Kur'ân'ın Çă̆daş Tefsiri. 12 Cilt. İstanbul: Yeni Ufuklar Neşriyat, 1990.

Begavî, Ebû Muhammed Muhyissunne el-Hüseyn b. Mes'ûd b. Muhammed el-Ferrâ. Me'âlimu't-tenzîl. thk. 'Abdurrezzâk elMehdî. 5. Cilt. Beyrut: Dâru İhyâi't-Türâsi'l-'Arabî, 1420. 
86 | M. ALTUNTAŞ / Tefsir Literatürü Işığında İsrâ Olayından Önce Nâzil Olan Sûrelerde Namaz

Beydâvî, Nâsıruddîn Ebû Sa'îd 'Abdullâh b. Ömer b. Muhammed eş-

Şîrâzî. Envâru't-tenzîl. thk. Muhammed Abdurrahman el-Maraşlı. 5

Cilt. Beyrut: Dâru İhyâi't-Türâsi'l-'Arabî, 1418.

Binol, Ali. "Kur'ân'da Geçen Tezekkî Kavramı Üzerine Bir Değerlendirme". Bozok Üniversitesi İlahiyat Fakültesi Dergisi 11/11 (Haziran 2017), 185-206.

Buhârî, Ebû 'Abdillâh Muhammed b. İsmâ‘îl. Sahîhu'l-Buhârî. 8 Cilt. İstanbul: Çağrı Yayınları, 1992.

Cessâs, Ahmed b. 'Alî Ebû Bekr er-Râzî. Ahkâmü'l-Kur'ân. thk. Muhammed Sâdık el-Kamhâvî. 5 Cilt. Beyrut: Dâru İhyâi' t-Türâsi'1'Arabî, 1405.

Demirci, Muhsin. Kur'ân Tefsirinde Farklı Yorumlar. 3 Cilt. İstanbul: İfav Yayınları, 2017.

Derveze, Muhammed 'İzzet. et-Tefsîru'l-hadîs. Kâhire: Dâru İhyâi'lKütübi'l-'Arabiyye, 1383.

Ebû 'Ubeyde, Ma'mer b. el-Müsennâ et-Teymî el-Basrî. Mecâzu'l-Kur'ân. thk. Muhammed Fuâd Sezgin. 2 Cilt. Kâhire: Mektebetü'l-Hancî, 1381.

Ebû Dâvûd, Süleyman b. el-Eşa's. Sünen. 5 Cilt. İstanbul: Çağrı Yayınları, 1992.

Ebûssuûd, Muhammed b. Muhammed b. Mustafâ el-'İmâdî. İşâdu'l'akli's-selîm. Beyrut - Lübnân: Dâru İhyâi't-Türâsi'l-'Arabî, 2010.

Ferrâ, Ebû Zekeriyyâ Yahyâ b. Ziyâd b. 'Abdillâh b. Manzûr ed-Deylemî. Me'âni'l-Kur'ân. thk. Ahmed Yûsuf en-Necâtî vd.. 3 Cilt. Misır: Dâru'l-Misriyye, ts.

Hamidullah, Muhammed. İslâm Peygamberi. çev. Salih Tuğ. 2 Cilt. İstanbul: İrfan Yayımcılık, 1995.

Harman, Ömer F. "İslâmiyet ve Kudüs”. Milel ve Nihal 16/1 (2019), 9-30.

Hâzin, 'Alâüddîn Alî b. Muhammed b. İbrâhîm. Lubâbu't-te'vîl. thk. Muhammed 'Alî Şâhîn. 4 Cilt. Beyrut: Dâru'l-Kütübi'l-'Illmiyye, 1415.

İbn 'Âşûr, Muhammed Tâhir. Tefsîru't-tahrîr ve't-tenvîr. 30 Cilt. Tunus: Dâru Sahnûn li'n-Neşr ve't-Tevzi', ts.

İbn 'Atiyye, Ebû Muhammed 'Abdülhak b. Gâlib b. 'Abdirrahmân. elMuharreru'l-vecîz. thk. 'Abdusselâm 'Abduşşâfî Muhammed. 5 Cilt. Beyrut: Dâru'l-Kütübi'l-'İlmiyye, 1422. 
M. ALTUNTAŞ / In the Light of Tafsīr Literature, Prayer (Salāt) in the Sūrahs Sent Down before the Event of Isrā' | 87

İbn Ebî Hâtim, Ebû Muhammed 'Abdurrahmân b. Muhammed b. İdrîs er-Râzî. Tefsîru'l-Kur'âni'l-'azîm. thk. Es'ad Muhammed et-Tayyib. 10 Cilt. Arabistan: Mektebetü Nizâr Mustafa el-Bâz, 1419.

İbn Ebî Zemenîn, Ebû 'Abdillâh Muhammed b. 'Abdillâh b. 'Îsâ. Tefsîru'lKur'âni'l-'azîz. thk. Ebû 'Abdillâh Hüseyin b. 'Ukkâşe - Muhammed b. Mustafâ el-Kenz. 5 Cilt. Misır: el-Fârûku'l-Hadîse, 2002.

İbn Hişâm, Ebû Muhammed Cemâlüddîn 'Abdülmelik. es-Sîretu'nnebeviyye. thk. Mustafâ eş-Şekkâ vd.. 4 Cilt. Beyrut: Dâru'l-hayr, 1995.

İbn Kuteybe, Ebû Muhammed 'Abdullâh b. Müslim ed-Dîneverî. Garîbü'lKur'ân. thk. Sa'îd el-Lihâm. b.y.: y.y., ts.

İbn Mâce, Ebû 'Abdillâh Muhammed b. Yezîd el-Kazvînî. Sünen. 2 Cilt. İstanbul: Çağrı Yayınları, 1992.

İbn Mücâhid, Ebu'l-Haccâc el-Mahzûmî. Tefsîru Mücâhid. thk. Muhammed 'Abdüsselâm Ebu'n-Nîl. Misır: Dâru'l-Fikri'lİslâmiyyi'l-Hadîse, 1989.

İbnü'l-Cevzî, Ebü'l-Ferec Cemâluddîn 'Abdurrahmân b. Alî b. Muhammed. Zâdü'l-mesîr. thk. 'Abdurrezzâk el-Mehdî. 4 Cilt. Beyrut: Dâru'l-Kitâbi'l-'Arabî, 1422.

Kurtubî, Ebû 'Abdillâh Muhammed b. Ahmed el-Ensârî. el-Câmiu' li ahkâmi'l-Kur'ân. 13 Cilt. Beyrut: Dâru'l-Fikr, 1995.

Kuşeyrî, 'Abdülkerîm b. Hevâzin b. 'Abdilmelik. Letâifü'l-işârât. thk. İbrâhîm el-Besyûnî. 3 Cilt. Mısır: el-Hey'etü'l-Mısriyyetü'l-'Âmme li'l-Kitâb, ts.

Mâverdî, Ebü'l-Hasen 'Alî b. Muhammed b. Habîb. en-Nüket ve'l-'uyûn. 6 Cilt. Beyrut - Lübnân: Dâru'l-Kütübi'l-'İlmiyye, 2012.

Mevdûdî, Ebü'l-A'lâ. Tefhîmu'l-Kur'ân. çev. Muhammed Han Kayanî vd.. 7 Cilt. İstanbul: İnsan Yayınları, 1996.

Mukâtil b. Süleymân, Ebü'l-Hasen b. Beşîr el-Ezdî el-Belhî. Tefsîru Mukâtil b. Süleymân. thk. Ahmed Ferîd. 3 Cilt. Beyrut: Dâru'l-Kütübi'l'İlmiyye, 2003.

Müslim, Ebû́'l-Hüseyn Müslim b. el-Haccâc el-Kuşeyrî. Sahîh. 3 Cilt. İstanbul: Çağrı Yayınları, 1992.

Nesâî, Ebû 'Abdirrahmân Ahmed b. Şu'ayb. Sünen. 8 Cilt. İstanbul: Çağn Yayınları, 1992. 
88 | M. ALTUNTAŞ / Tefsir Literatürü Işı̆̆ı̆nda İsrâ Olayından Önce Nâzil Olan Sûrelerde Namaz

Nîsâbûrî, Nizâmuddîn el-Hasen b. Muhammed b. el-Hüseyn el-Kummî.

Garâibu'l-Kur'ân. thk. Zekeriyyâ 'Umeyrât. 6 Cilt. Beyrut: Dâru'lKütübi'l-'İlmiyye, 1416.

Olgun, Tahir. Müslümanlıkta İbâdet Tarihi. Ankara: Akçağ Yayınları, 1998. Öztürk, Mustafa - Ünsal, Hadiye. Kur'ân Tarihi. Ankara: Ankara Okulu Yayınları, 2016.

Râzî, Ebû 'Abdillâh Muhammed b. 'Ömer Fahruddîn. Mefâtîhu'l-gayb. 32 Cilt. Beyrut: Dâru İhyâi't-Türâsi'l-'Arabî, 1420.

Sa‘lebî, Ebû İshâk Ahmed b. Muhammed b. İbrâhîm en-Nîsâbûrî. el-Keşf ve'l-beyân. thk. el-İmâm Ebî Muhammed b. 'Âşûr. 10 Cilt. Beyrut: Dâru İhyâi't-Türâsi'l-'Arabî, 2002.

Semerkandî, Ebü'l-Leys Nasr b. Muhammed b. Ahmed b. İbrâhîm. Bahru'l-'ulûm. 3 Cilt. b.y.: y.y., ts.

Süfyân es-Sevrî, Ebû 'Abdillâh b. Saî'd b. Mesrûk el-Kûfî. Tefsîru Süfyân es-Sevrî. Beyrut - Lübnân: Dâru'l-Kütübi'l-'Illmiyye, 1983.

Şimşek, M. Sait. Hayat Kaynă̆ı Kur'ân Tefsiri. 5 Cilt: İstanbul: Beyan Yayınları, 2012.

Taberî, Ebû Ca'fer Muhammed b. Cerîr. Câmiu'l-beyân. thk. Sıdkı Cemîl el-'Attâr. 13 Cilt. Beyrut: Dâru'l-Fikr, 2001.

Tirmizî, Ebû 'Îsâ Muhammed b. 'Îsâ b. Sevre. Sünen. 5 Cilt. İstanbul: Çağrı Yayınları, 1992.

Tüsterî, Ebû Muhammed Sehl b. 'Abdillâh b. Yûnus b. Refî'. Tefsîru'tTüsterî. thk. Muhammed Bâsil 'Uyûnu's-Sûd. Beyrut: Dâru'lKütübi'l-'İlmiyye, 1423.

Vâhidî, Ebü'l-Hasen 'Alî b. Ahmed b. Muhammed b. 'Ali en-Nîsâbûrî. elVecîz. thk. Safvân 'Adnân Dâvûdî. Beyrut: Dâru'l-Kalem - edDâru'ş-Şâmiyye, 1415.

Yazır, Elmalılı Muhammed Hamdi. Hak Dini Kur'ân Dili. 10 Cilt. İstanbul: Yenda Yayınları, 2001.

Zemahşerî, Ebü'l-Kâsım Mahmûd b. 'Ömer b. Muhammed. el-Keşşâf. 4 Cilt. Beyrut: Dâru'l-Kütübi'l-'İlmiyye, 1995. 